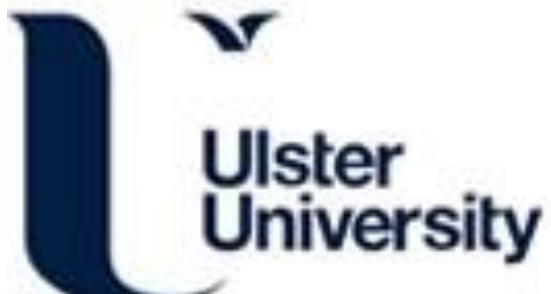

\section{Experimental Performance Analysis of a Novel Sand Coated and Sand Filled Polycarbonate Sheet Based Solar Air Collector}

Das, B., Mondol, J., Negi, S., Smyth, M., \& Pugsley, A. (2021). Experimental Performance Analysis of a Novel Sand Coated and Sand Filled Polycarbonate Sheet Based Solar Air Collector. Renewable Energy, 164, 9901004. https://doi.org/10.1016/j.renene.2020.10.054

Link to publication record in Ulster University Research Portal

\section{Published in:}

Renewable Energy

Publication Status:

Published (in print/issue): 01/02/2021

DOI:

10.1016/j.renene.2020.10.054

\section{Document Version}

Author Accepted version

\section{General rights}

Copyright for the publications made accessible via Ulster University's Research Portal is retained by the author(s) and / or other copyright owners and it is a condition of accessing these publications that users recognise and abide by the legal requirements associated with these rights.

\section{Take down policy}

The Research Portal is Ulster University's institutional repository that provides access to Ulster's research outputs. Every effort has been made to ensure that content in the Research Portal does not infringe any person's rights, or applicable UK laws. If you discover content in the Research Portal that you believe breaches copyright or violates any law, please contact pure-support@ulster.ac.uk. 


\section{Journal Pre-proof}

Experimental performance analysis of a novel sand coated and sand filled polycarbonate sheet based solar air collector

Biplab Das, Jayanta Deb Mondol, Sushant Negi, Mervyn Smyth, Adrian Pugsley

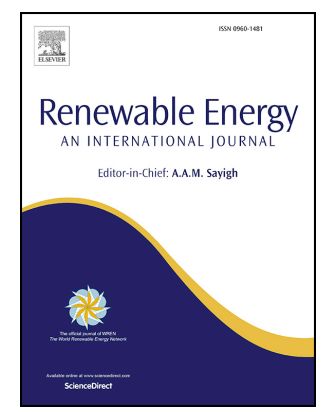

PII:

S0960-1481(20)31620-7

DOI: https://doi.org/10.1016/j.renene.2020.10.054

Reference: RENE 14344

To appear in: Renewable Energy

Received Date: 15 July 2020

Revised Date: 5 October 2020

Accepted Date: 13 October 2020

Please cite this article as: Das B, Mondol JD, Negi S, Smyth M, Pugsley A, Experimental Performance Analysis of a Novel Sand Coated and Sand Filled Polycarbonate Sheet Based Solar Air Collector, Renewable Energy, https://doi.org/10.1016/j.renene.2020.10.054.

This is a PDF file of an article that has undergone enhancements after acceptance, such as the addition of a cover page and metadata, and formatting for readability, but it is not yet the definitive version of record. This version will undergo additional copyediting, typesetting and review before it is published in its final form, but we are providing this version to give early visibility of the article. Please note that, during the production process, errors may be discovered which could affect the content, and all legal disclaimers that apply to the journal pertain.

(c) 2020 Elsevier Ltd. All rights reserved. 


\section{Experimental Performance Analysis of a Novel Sand Coated and Sand Filled}

\section{Polycarbonate Sheet Based Solar Air Collector}

Biplab Das ${ }^{1,2 *}$, Jayanta Deb Mondol ${ }^{2}$, Sushant Negi ${ }^{1}$, Mervyn Smyth $^{2}$, Adrian Pugsley ${ }^{2}$

${ }^{1}$ Department of Mechanical Engineering, NIT Slchar, Assam-788010, India

${ }^{2}$ Belfast School of Architecture and the Built Environment, CST, Ulster University, Northern Ireland, UK.

*Corresponding Email- b.das@ulster.ac.uk / biplab.2kmech@gmail.com 


\section{Sheet Based Solar Air Collector}

\section{Abstract:}

4 An experiment was conducted to investigate the performance of a novel sand coated and sand filled 5 (SCSF) polycarbonate sheet based solar air collector (SAC) under controlled indoor conditions with variable air flow rates and solar inputs. The performance of this novel absorber was compared with aluminium absorber (with and without sand coating). The results indicated that due to the presence of sand coating over the absorber, the rate of heat transfer was enhanced by redistribution of air flow. Further, the presence of sand within the poly carbonate sheet acted as a thermal heat storage medium that might be used during off-sunshine hours. Further, the increment in mass flow rate by $87 \%$ lead to decrement in the magnitudes of stored energy by $10-24 \%$ and but the average discharging efficiency was increased by $15 \%$. The maximum thermal efficiency of the proposed collector was found to be $42 \%$ during charging. Reduction of air gap from $5 \mathrm{~cm}$ to $3 \mathrm{~cm}$ resulted in $11 \%$ higher thermal efficiency for sand coated aluminium absorber based SAC. It was found that the SAC with storage provided $39 \%$ and $20 \%$ higher thermal efficiency than that of the black paint coated aluminium absorber and sand coated aluminium absorber, respectively.

Keywords: Solar air collector; sand coating; sensible heat storage; charging efficiency; discharging efficiency

\section{Introduction}

Solar air collectors are widely used to transform the incoming solar radiation into useable form such as hot air, which can be used to dry agricultural products, space heating, and energy storage applications. The lower setup and operating cost of solar air collector (SAC) in comparison to other conventional energy sources make it more feasible solutions especially for the small-scale farmers. These types of collectors have many attractive advantages over water heating collectors such as higher working pressure range, fewer problems of corrosion or leakage, and non-freezing behaviour 
follows: vacuum tube heaters: $71.1 \%$, flat plate collectors: $22.1 \%$, unglazed water heaters: $6.3 \%$, and solar air collectors $0.4 \%$ [3].

It is obvious that the thermal applications of SACs are still limited; due to poor heat transfer between the air and the absorber plate because of development of laminar sublayer and lower thermal capacity of air [4]. Moreover, cloudy weather conditions and off sunshine hours or night restricts the efficient use of SAC for agricultural drying and heating applications. The possible solution to overcome this issue is to provide heat storage capability so that thermal energy can be stored in the daytime, and later it can be used in night as well as in peak load hour. One of the effective ways to improve the heat transfer from absorber plates is surface modification, which helps to generate the secondary flow in the collector and increase the surface area. Das et al. [4] experimentally investigated the performance of SAC with sand coated absorber plate at variable air mass flow rate ranging from 0.01 to $0.02 \mathrm{~kg} / \mathrm{s} / \mathrm{m}^{2}$ and radiation levels of 400,600 , and $800 \mathrm{~W} / \mathrm{m}^{2}$. Results indicated that the thermal efficiency of the collector improved by $17 \%$ for the sand coated absorber plate compared to the plain absorber, at a mass flow rate of $0.02 \mathrm{~kg} / \mathrm{s} / \mathrm{m}^{2}$ and radiation level $800 \mathrm{~W} / \mathrm{m}^{2}$. Karwa and Srivastava [5] numerically investigated the effect of absorber plate with v-down discrete rib roughness on the thermal performance of SAC. The thermal efficiency of the SAC with roughened duct was obtained between $6 \%$ and $26 \%$ higher when compared to the performance of smooth duct SAC. Debnath et al. [6], Karim and Hawlader [7] found that use of corrugated absorber plate significantly improves the thermal performance of SAC, this was due to the improved turbulence effect and increment of the heat transfer area. Lati et al. [8] tested the performance of collectors with sand coated absorber plates. It was found that absorber plate coated with finer sand particles have better performance, maximum efficiency of $62.1 \%$ was noticed when the sand particle diameter was $0.063 \mathrm{~mm}$. Singh et al. [9] observed that SAC with circular jet impingement significantly enhances its thermal performance, and recommended to use bed porosity of $98 \%$, mass flow rate of $0.04 \mathrm{~kg} / \mathrm{s}$, and impinging plate perforation of $0.48 \%$ to achieve best 
collector colors with and without glazing. The maximum efficiency of $85 \%$ at mass flow rate of

$0.036 \mathrm{~kg} / \mathrm{s}$ was found for the black painted SAC with glazing. Velmurugan and Kalaivanan [11] studied the effect of four different geometrical arrangements such as wire mesh, finned plate, flat plate and rough plate on energy and exergy performance of SAC with single/dual pass. Wire mesh SAC with dual pass provided highest temperature of $25.2^{\circ} \mathrm{C}$ and maximum efficiency of $76.46 \%$ than other conditions. Special selective coatings on the surface of absorber plate such as nickel-tin [12], mixture of vanadium and aluminium oxides [13] were also employed to obtain high effectiveness in solar air collectors.

Several researchers have also improved the performance of SACs by integrating it with heat storage media such as sensible or latent materials. The characteristics of latent heat storage such as high heat capacity and constant charging and discharging temperature make it more appealing; however poor thermal conductivity of these solid phase materials is one of the major drawbacks. Consequently, high thermal resistance has been noticed as the material deposits on the heat transfer surface during the discharging process [14]. Due to easier availability, lower cost, ease of fabrication, and higher thermal conductivity, the sensible storage materials are generally preferred over latent heat storage materials [15]. Kalaiarasi et al. [16] analysed the thermal performance of SAC with sensible heat storage medium such as synthetic oil (Therminol-55), and reported maximum thermal efficiency of $70.8 \%$, when the mass flow rate was $0.028 \mathrm{~kg} / \mathrm{s}$. Saxena et al. [17] constructed SAC with heat storing media such as granular carbon and the maximum thermal efficiency of $73.6 \%$ and $20.7 \%$ was achieved under forced and natural convection mode, respectively. Laksmi et al. [18] experimentally investigated the performance of SAC with trapezoidal corrugated absorber plate and gravel as sensible heat storage media. The maximum energy efficiency was $58.16 \%$, while the exergy efficiency was $14.6 \%$. Aissa et al. [19] used granite stones for developing a flat SAC with heat storage system, and measured the output of SAC by varying air mass flow rates from $0.016 \mathrm{~kg} / \mathrm{s}$ to $0.08 \mathrm{~kg} / \mathrm{s}$ under forced convection mode, They 
achieving optimum outlet air temperature for the heating applications. Mohanraj and Chanderasekar [20] concluded that the sand with aluminium scraps as a packing material facilitates to maintain steady air temperature inside the drying chamber. Also, the inclusion of storage media has significantly increased the drying time by about 4 hours per day. Ramadan et al. [21] examined the thermal performance of SAC with limestone and gravel as heat storage materials, and observed that the gravel gave better results than lime stone. It is also observed that air mass flow rate up to 0.05 $\mathrm{kg} / \mathrm{s}$ has shown increment in thermohydraulic efficiency, but beyond that it has insignificant effect, thus it is recommended to use mass flow rate equal to $0.05 \mathrm{~kg} / \mathrm{s}$ or lower to have a lower pressure drop across the system. Murali et al. [22] outlined that use of aluminium cans with aluminium scraps as storage media for SAC gives better heat transfer coefficient and instantaneous efficiency, when the air mass flow rate was $0.025 \mathrm{~kg} / \mathrm{s}$. Abuska et al. [23] have measured the efficiency of SAC with cherry powder and cherry pits, and noticed that SAC with cherry pits have improved thermal efficiency of $27.03 \%$ in comparison to SAC with powdered cherry pits. Saxena et al. [24] experimentally investigated the use of SAC with granular carbon and mixed desert as sensible heat storage materials. Maximum thermal efficiency of $20.78 \%$ and $80.05 \%$ was observed under natural and forced convection mode, respectively. Dhote and Thombre [25] determined the influence of change in inclination such as $0^{\circ}, 15,30^{\circ}, 45^{\circ}, 60^{\circ}, 75^{\circ}, 90^{\circ}$ and storage oil quantity such as $50,75,100$ litre on the overall efficiency of SAC and the maximum efficiency was $16.88 \%$ at inclination of $60^{\circ}$ and storage quantity of 50 litre. Chaouch et al. [26] developed a forced convection based solar dryer having pebbles as heat storage material. It was found that the efficiency of SAC with storage capability improved by $28 \%$ than the system without storage. The designed solar dryer was also very much capable of maintaining its efficiency for an hour after the sunset. Prasad et al. [27] performed their study using wire mesh as packing material to develop SAC, and further varied the air mass flow rate between 0.0159 and $0.0347 \mathrm{~kg} / \mathrm{s}-\mathrm{m}^{2}$ to evaluate the heat transfer and friction characteristics. It has been observed that the heat transfer coefficient was increased with the 
thermal performance of the SAC with sensible storage materials was considerably higher than the system without storage. An optimum thickness of the storage material of about $0.12 \mathrm{~m}$ was found to be convenient for drying different agriculture products. The mathematical model of Naphon [29] showed that the thermal efficiency of SAC with porous media improved by $25.9 \%$ than that of without porous media. Thakur et al. [30] enhanced the performance of SAC using wire mesh screens in layer by layer manner to fabricate the packed bed. It was observed that both friction factor and heat transfer coefficient were strongly influenced by the geometrical arrangements of wire mesh screens. Also, it was noticed that the volumetric heat transfer coefficient increased with the decrease in porosity. Saravanakumar and Mayilsamy [31] found that the thermal efficiency of SAC with gravel and iron was $20 \%$ higher in comparison to SAC with other types of selected storage materials. Moreover, the inclusion of heat storage materials increased the collector efficiency and outlet temperature by 10-20\%. Vijayan et al. [32] developed a low cost solar air collector integrated with pebbles packed bed as sensible heat storage medium for the drying of bitter gourd slices. The average exergy efficiencies and pickup values were found in the range of $28.2-40.6 \%$ and $17.1-54.2 \%$ for the mass flow rates of $0.0141 \mathrm{~kg} / \mathrm{s}$ to $0.0872 \mathrm{~kg} / \mathrm{s}$, respectively. A summary of performances of various solar air collectors using different sensible heat storage materials are presented in Table 1.

Although many researchers have discussed the performance enhancement of SAC by modifying the surface of absorber plate or employing sensible heat storage media, but research on the use of natural materials like as sand as coating and heat storage materials are scarce in literature. A few references $[4,8]$ show the performance of SACs using sand as coating material to modify the absorber's surface, while the references $[20,24,28,31]$ show the performance of SAC having sand as storage materials. But, none among those proposed designs have attempted to use sand as coating and heat storage materials (i.e., sand coated and sand filled) successively. Furthermore, multi walled polycarbonate sheet based SAC has not been well explored yet. Hence, this study 
131 following key features: (i) black painted sand coating is used to modify the surface of the absorber

132 for better heat transfer; (ii) sand is used as sustainable and eco-compatible sensible heat storage

133

134 material; and (iii) multiwall poly carbonate sheet is used as base absorber material instead of traditional aluminium/copper absorber plate. Finally, the performance of proposed SAC was compared with the traditional black painted sand coated aluminium absorber under similar working conditions.

\section{Experimental set up}

In the present study sand is considered as the thermal storage materials for evaluating the thermal performance of the sustainable and eco-compatible solar air collector. The primary aim was to heating air using solar energy and to incorporate storage system so that thermal energy can be stored in the daytime, and later it can be used in night as well as in peak load hour to maintain the air temperature. The main experimental setup consists of black painted sand coated polycarbonate sheet filled with sand (Fig. 1a). Further, the previously made thermal collector presented by Das et al. [4] is used with modified air gap for comparison. The function of the polycarbonate sheet was twofold: the upper surface acts as an absorber while the multiwall helps to store the sand thus the combined system acts as a collector cum storage. Further, the presence of sand controls to maintain the temperature of the polycarbonate reaching at higher level thus reduces the chances of degradability under higher solar insolation. Differential Scanning Calorimetry (DSC) was used to derive information regarding the amount of heat required to increase the sample temperature. The heat flow $(\mathrm{mW})$ function with a blank curve correction was provided for samples heated at $5^{\circ} \mathrm{C}$ per minute under $\mathrm{N}_{2}$ environment from 30 to $600^{\circ} \mathrm{C}$ as displayed in Fig. 1b. The DSC analysis of pure sand is performed to study the crystallization process and latent heat involved in the process. A sharp downfall in the heat flow is recorded with a peak position located at $\sim 575{ }^{\circ} \mathrm{C}$ which demonstrates the crystallization of the materials due to the exothermic process. This phenomena is 


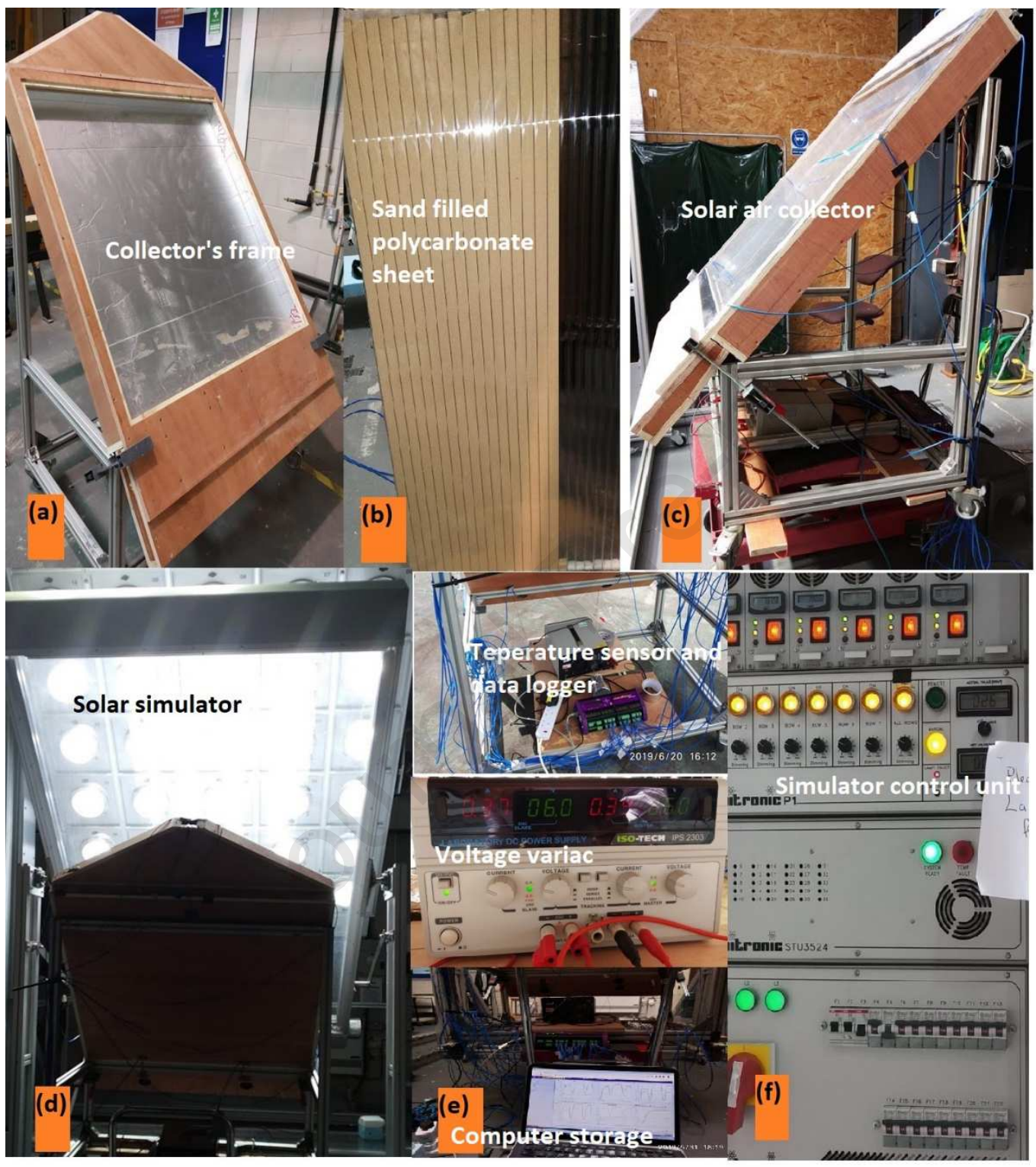

Fig. 1. Pictorial view of the experimental setup. (a) Frame of the collector; (b) Sand filled polycarbonate sheet; (c) Side view of the collector under the solar simulator; (d) Solar simulator and collector during experimentation; (e) Temperature sensors, data logger, voltage variac, computer for online storing; (f) Voltage regulator for simulator. 
The experimental setup of the SCSF collar collector can be seen in Fig. 1. The collector has a cross-sectional area of $1.44 \mathrm{~m}^{2}$ and an absorber plate of $0.97 \mathrm{~m} \mathrm{x} 0.97 \mathrm{~m}$. Further, all the technical specifications of the storage based solar collector kept same as that of Das et al. [4]. However, to adjust the thickness of the multi-wall polycarbonate sheet having thickness of $0.02 \mathrm{~m}$, the air gap was reduced to $0.03 \mathrm{~m}$ compared to that of the $0.05 \mathrm{~m}$ for the case of Das et al. [4]. The back side was insulated by using $0.02 \mathrm{~m}$ thick Thermocol. The outer body of the collector was made of 0.015 m thick plywood. The top surface of the polycarbonate sheet was first coated with black paint and then a layer of black painted sand was coated over it. To make the sand coating, mixture of black paint and preheated sand were painted over the absorber. For the storage, the dried sand was inserted in between the multi-walls of the polycarbonate sheet. A single transparent glazing made up of Perspex sheet having thickness of $0.005 \mathrm{~m}$ was employed to reduce the top losses. Two DC fans each of $12 \mathrm{~V}$ capacity were utilised to blow the air from the bottom (considered as the inlet) of the collector. A voltage variac was used to supply controlled DC power to the fans.

Solar simulator with variable radiation level of $800 \mathrm{~W} / \mathrm{m}^{2}$ and $400 \mathrm{~W} / \mathrm{m}^{2}$ are used as a source of light and tests are performed at the laboratory of Centre for Sustainable Technologies, Ulster University. The radiation level was measured by a pyranometer by keeping it at different position of the collector. The average intensity on the collector surface varied between $\pm 15 \mathrm{~W} / \mathrm{m}^{2}$. The collector and simulator lamp array were kept parallel to each other and were at $45^{\circ}$ inclined to horizontal. The exit air velocity was measured with the help of an anemometer and the velocity was 
187 the temperature reading at an interval of 1 minute. The accuracy of the instruments and the involved

188 uncertainties were evaluated using equations reported by Das et al. [4] and the values are shown in 189 Table 2.

190

191

192

Table 2: Accuracy and percentage errors for various instruments.

\begin{tabular}{lcllc}
\hline Instrument & Make/ Model & Accuracy & Range & \% error \\
\hline Pyranometer & Kipp \& Zonen & $\pm 5 \mathrm{~W} / \mathrm{m}^{2}$ & $0-4000 \mathrm{~W} / \mathrm{m}^{2}$ & 2.5 \\
Anemometer & Trotec, TA300 & $\pm 0.01 \mathrm{~m} / \mathrm{s}$ & $0-25 \mathrm{~m} / \mathrm{s}$ & 0.5 \\
Differential & OMEGA, & $\pm 0.05 \mathrm{hpa}$ & $0-100 \mathrm{hpa}$ & 5 \\
manometer & HHC280 & & & \\
T-type thermocouple & $\begin{array}{l}\text { Laboratory of } \\
\text { Ulster university }\end{array}$ & $\pm 0.5^{\circ} \mathrm{C}$ & $0-300{ }^{\circ} \mathrm{C}$ & 1.25 \\
& & & \\
\hline
\end{tabular}

194

3. Mathematical formulation

196 Steady flow energy equation for solar air collectors is given by $[4,8]$

197 Accumulated energy $\left(Q_{a c}\right)=$ Useful heat energy gain $\left(Q_{u}\right)+$ Absorbed energy by the

198 absorber/storage $\left(Q_{a b}\right)+$ Lost energy $\left(Q_{\text {loss }}\right)$

199 Accumulated energy can be evaluated as:

200

$$
Q_{a c}=I A_{c}
$$

201 where, $I$ is the magnitudes of the solar radiation and $A_{c}$ is the collector area.

202 Useful heat gain by the moving air is evaluated as: 
204 where, $m_{a}$ is the air mass flow rate, $C_{p, a}$ is the specific heat of air, $T_{a, \text { out }}$ is the outlet air temperature and $T_{a, i n}$ is the inlet air temperature.

206 The absorbed energy in the storage $\left(Q_{a b}\right)$ is calculated by

207

$$
Q_{a b}=m_{p} C_{p, s}\left(d T_{p, \text { average }} / d t\right)
$$

where, $m_{p}$ is the mass of the sensible storage material (i.e., sand), $C_{p, s}$ is the specific heat of sand,

The energy loss $\left(Q_{\text {loss }}\right)$ is given by

$$
Q_{\text {loss }}=U_{c} A_{s c}\left(T_{p, \text { average }}-T_{e}\right)
$$

212 where, $U_{c}$ is the overall heat loss coefficient, $A_{s c}$ is the area of the absorber, $T_{p, \text { average }}$ is the average temperature of sand air, and $T_{e}$ is the temperature of the environment.

The air mass flow rate can be evaluated as

$$
m=\rho A_{s c} V
$$

where, $\rho$ is the density of the air and $V$ is the air speed.

217 The thermal performance of the SCSF polycarbonate sheet based SAC is based on the heat transfer from the hot air to the sand in the reservoir and vis versa. The charging efficiency or storing efficiency $\left(\eta_{s, c}\right)$ is estimated from the ratio of the amount of stored energy in the sand to the total amount of incident solar radiation.

$$
\eta_{s, c}=Q_{a b} / I A_{s c}
$$

In storage based solar collector systems, two different thermal efficiencies can be calculated: heat collection (charge) efficiency and heat retrieval (discharge) efficiency. quantity of heat transferred to the air and the total solar irradiance incident [28]. 
227 The thermal efficiency of the collectors $\left(\eta_{t, d}\right)$ during discharging is defined as the ratio of the total

228 quantity of heat transferred to the air and the total energy stored in the storage $\left(Q_{a b}\right)$.

$$
\eta_{t, d=} Q_{u} /\left(Q_{a b}\right)
$$

\section{Results and discussion}

\subsection{Charging mode}

\subsubsection{Variation of temperature difference}

The variation in temperature difference between the glazing and the inlet air ( $\Delta T_{\_}$glazing), the absorber and the inlet air ( $\left.\Delta T \_a b s o r b e r\right)$, and the outlet air and the inlet air $\left(\Delta T \_a i r\right)$ with time is shown in Fig. 2a-d. At a lower mass flow rate of $0.0096 \mathrm{~kg} / \mathrm{s}$ and at lower radiation level of 400 $\mathrm{W} / \mathrm{m}^{2}$, a continuous increase in the magnitude of the temperature differences is observed with time. Results also indicated that $\Delta T_{-}$absorber is always higher than the other values $\left(\Delta T \_a i r\right.$ and $\Delta T \_$_lazing). This may be due to the lower rate of heat transfer by the air. Conversely, lower values of $\Delta T \_$glazing is an indication of lower values of top heat loss from the collector. With the increase in mass flow rate to $0.018 \mathrm{~kg} / \mathrm{s}$ (Fig. 2b), the magnitude of all temperature differences are found to reduce, due to an increase in the heat extraction rate by the working fluid (air). Furthermore, it is

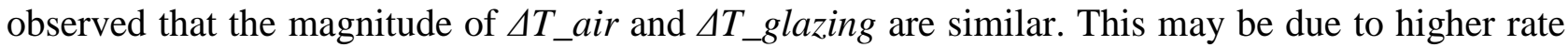
of reduction of the outlet air temperature compared to that of the glazing temperature. Again, a

247 reduction in the outlet air temperature is due to the lower retention time of the air within the collector due to the increase in the mass flow rate. At higher level of radiation $\left(800 \mathrm{~W} / \mathrm{m}^{2}\right)$, the trend remains the same but the values increase. The values of $\Delta T_{-}$absorber, $\Delta T_{-}$air, and 
252 temperature by $38 \%$ and $64 \%$ at lower and higher levels of solar radiation, respectively.

253

254

255

256

257

258

259

260

261

262

263

264

265

266

267

268

269

270

271

\subsubsection{Variation of storage temperature and stored energy}

The variation of the average storage (sand) temperature at three different positions with respect to time are shown in Fig. 3a-d for two different solar radiation levels. Positions are fixed along the axial direction near the inlet (referred to as $T_{\text {bottom }}$ ), midsection (referred to as $T_{\text {middle }}$ ) and near the exit (referred to as $T_{t o p}$ ). Each temperature reading is the average of three different sensors fitted in the radial direction at the same axial location. Results indicated that the temperature of the sand initially increases rapidly in the initial $50 \mathrm{~min}$. due to the absorbance of solar radiation. Thereafter the rate of increase reduces due to an increase in the temperature difference between the incoming air and the temperature of the absorber resulting in a higher rate of extraction of heat by the travelling air. It is noted that the differences in temperature between the three locations increases with time. The maximum average storage temperature of $54^{\circ} \mathrm{C}$ is observed with a maximum deviation of $4^{\circ} \mathrm{C}$ between the inlet and outlet sections. Furthermore, with the increase in the mass flow rate to $0.018 \mathrm{~kg} / \mathrm{s}$ (Fig. 3b), the maximum average temperature is $47^{\circ} \mathrm{C}$ with a maximum deviation of $2^{\circ} \mathrm{C}$. Apart from the magnitude, a similar trend is observed at the higher radiation level of $800 \mathrm{~W} / \mathrm{m}^{2}$ (see Fig. $3 \mathrm{c}-\mathrm{d}$ ). As can be seen, the maximum temperature varies between 70 to $84^{\circ} \mathrm{C}$. However, the deviation in temperature between the inlet and outlet varies between 6 and $8^{\circ} \mathrm{C}$. This deviation is due to the reduction in the driving force (i.e. temperature difference between the air and the absorber) and thus the heat absorption capacity of the fluid as it moves in the axial direction. Eventually the axial temperature of air increases gradually. 

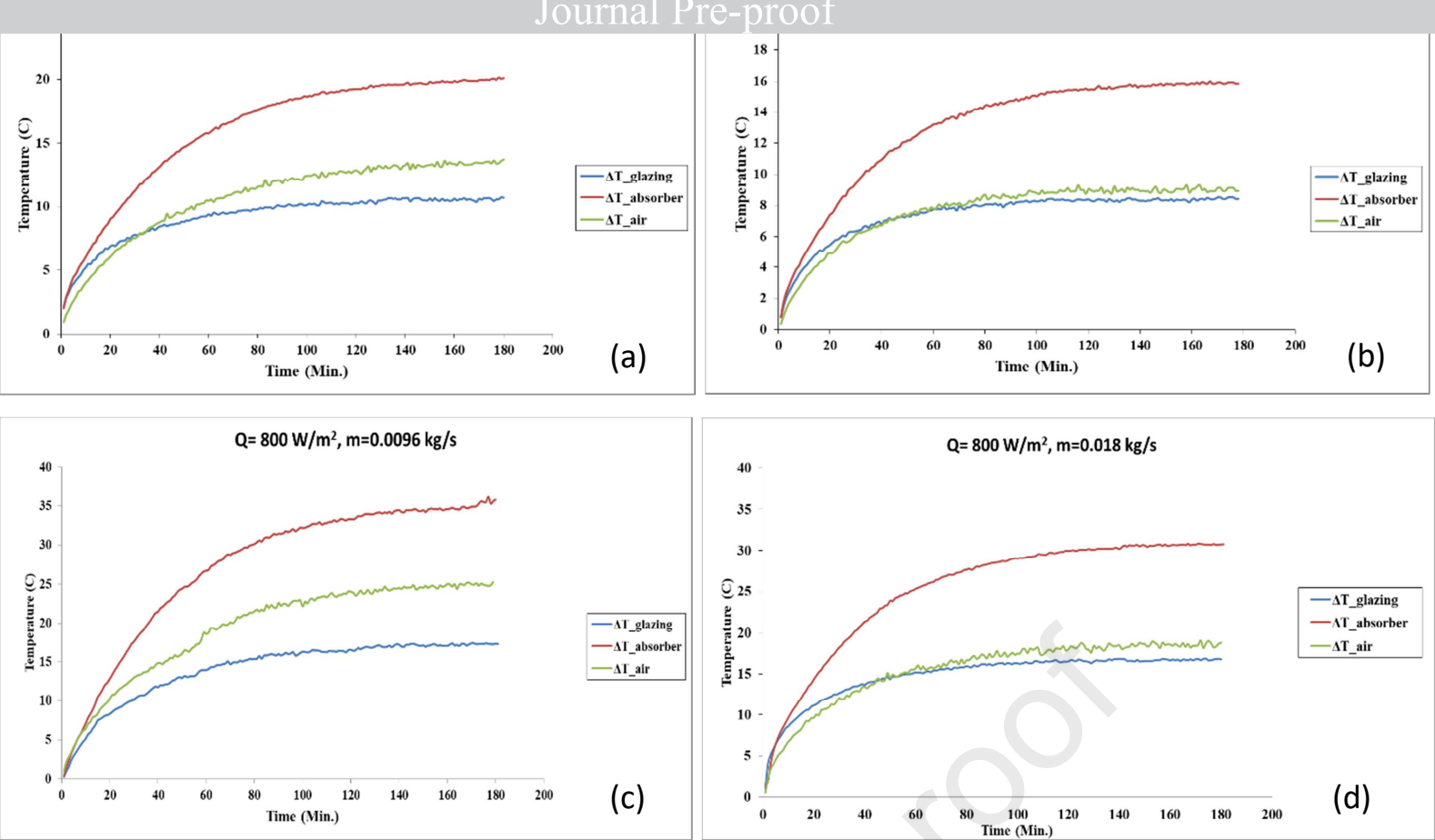

Fig. 2. Variation of temperature difference. (a)

(a) $Q=400 \mathrm{~W} / \mathrm{m}^{2}, m=0.0096 \mathrm{~kg} / \mathrm{s}$;

(b) $Q=400 \mathrm{~W} / \mathrm{m}^{2}$, $m=0.018 \mathrm{~kg} / \mathrm{s} ;$ (c) $Q=800 \mathrm{~W} / \mathrm{m}^{2}, m=0.0096 \mathrm{~kg} / \mathrm{s} ;$ (d) $Q=800 \mathrm{~W} / \mathrm{m}^{2}, m=0.018 \mathrm{~kg} / \mathrm{s}$.

Variation of the total stored energy in the sand with time is shown in Fig. 4a-b. As can be seen, the magnitude of stored energy increases with time due to absorption of solar radiation. Initially, the rate of increase is high due to higher absorption capacity of the sand because of the lower temperature. With the passage of time, the surface temperature of the absorber (and thus the storage temperature) increases resulting in a higher rate of extraction of heat by the air. At the same time due to higher system temperature, the level of the top (leakage) losses increases. At lower levels of solar radiation $\left(400 \mathrm{~W} / \mathrm{m}^{2}\right)$, the increase in the air mass flow rate results in a decrease in the levels of the heat storage rate due to the higher rate of heat extraction by the flowing air. This may be due to lower potential retention of the flowing air that allows the sand to store more energy. At higher solar radiation levels $\left(800 \mathrm{~W} / \mathrm{m}^{2}\right)$, the variation with time is similar to lower solar radiation, but the amount of stored energy is higher. Furthermore, the increase in air mass flow rate resulted in a decrease in the stored energy for all mass flow rates, mainly due to the increase in extraction rate of thermal energy. Overall, the stored energy decreased by 10 to $24 \%$ for an increase in air mass flow rate by $87 \%$. 

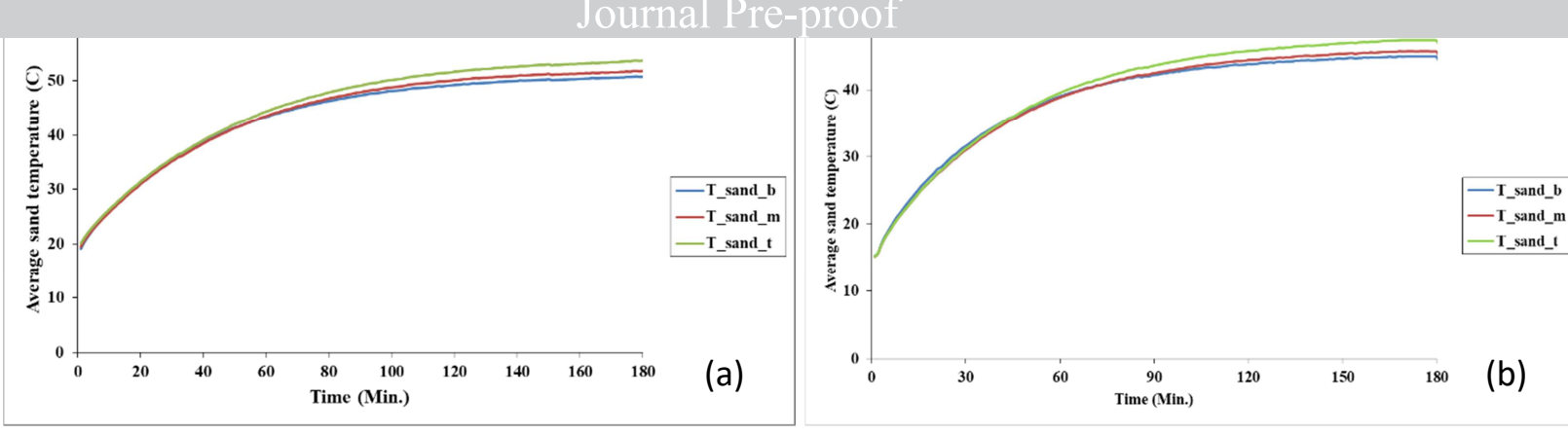

(b)

291
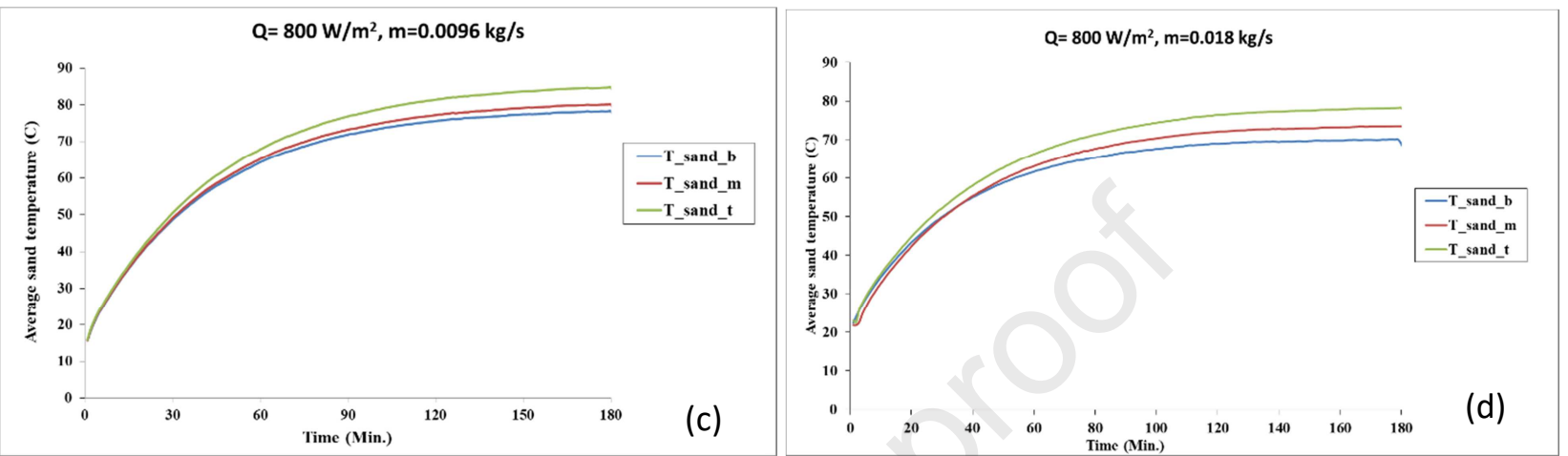

Fig. 3. Variation of average storage (sand) temperature during charging. (a) $Q=400 \mathrm{~W} / \mathrm{m}^{2}, m=0.0096$

$\mathrm{kg} / \mathrm{s}$; (b) $Q=400 \mathrm{~W} / \mathrm{m}^{2}, m=0.018 \mathrm{~kg} / \mathrm{s} ;$ (c) $Q=800 \mathrm{~W} / \mathrm{m}^{2}, m=0.0096 \mathrm{~kg} / \mathrm{s}$; (d) $Q=800 \mathrm{~W} / \mathrm{m}^{2}, m=0.018 \mathrm{~kg} / \mathrm{s}$.

\subsubsection{Variation of charging efficiency}

The variation in charging efficiency with time for various mass flow rates of air is depicted in Fig.

5a-b. As can be seen, the charging efficiency initially increases but this is followed by a drop off over time. It may be inferred that from the total incident radiation, a portion of the heat is stored in the sand, a portion is absorbed by the flowing air and remainder is lost. An initial increase in the charging efficiency resulted from the increase in the magnitude of heat stored in the sand. And a comparatively lower amount of heat carried away by the travelling air due to lower temperature gradient between the incoming air and the surface of the absorber. Further, with the passage of time, the increase in heat storage within the sand increases the surface temperature of the absorber which in turn increases the amount of heat extracted by the flowing air.

It is important to mention here that higher system temperature also results in higher heat loss to the environment. Since the primary aim of the present setup is to use it as a collector, thus the lower value of charging efficiency can be accepted, if the conversion efficiency of the collector 
308 almost 60 min., the fraction of heat absorbed by the flowing air and the sand takes a steady trend.

309 The initial increase in air mass flow rate, leads to increase in heat absorbing capacity of the

310 travelling air, resulting in a lower value of maximum charging efficiency. Thus, it can be concluded

311 that a mass flow rate of $0.0012 \mathrm{~kg} / \mathrm{s}$ is better in terms of charging efficiency of the collector. The

312 variation of the charging efficiency at a higher intensity $\left(800 \mathrm{~W} / \mathrm{m}^{2}\right)$ shows similar trend to the low

313 intensity $\left(400 \mathrm{~W} / \mathrm{m}^{2}\right)$ (Fig. 5b). The deviation of the charging efficiency becomes insignificant after

314 a certain time for all the air mass flow rate.

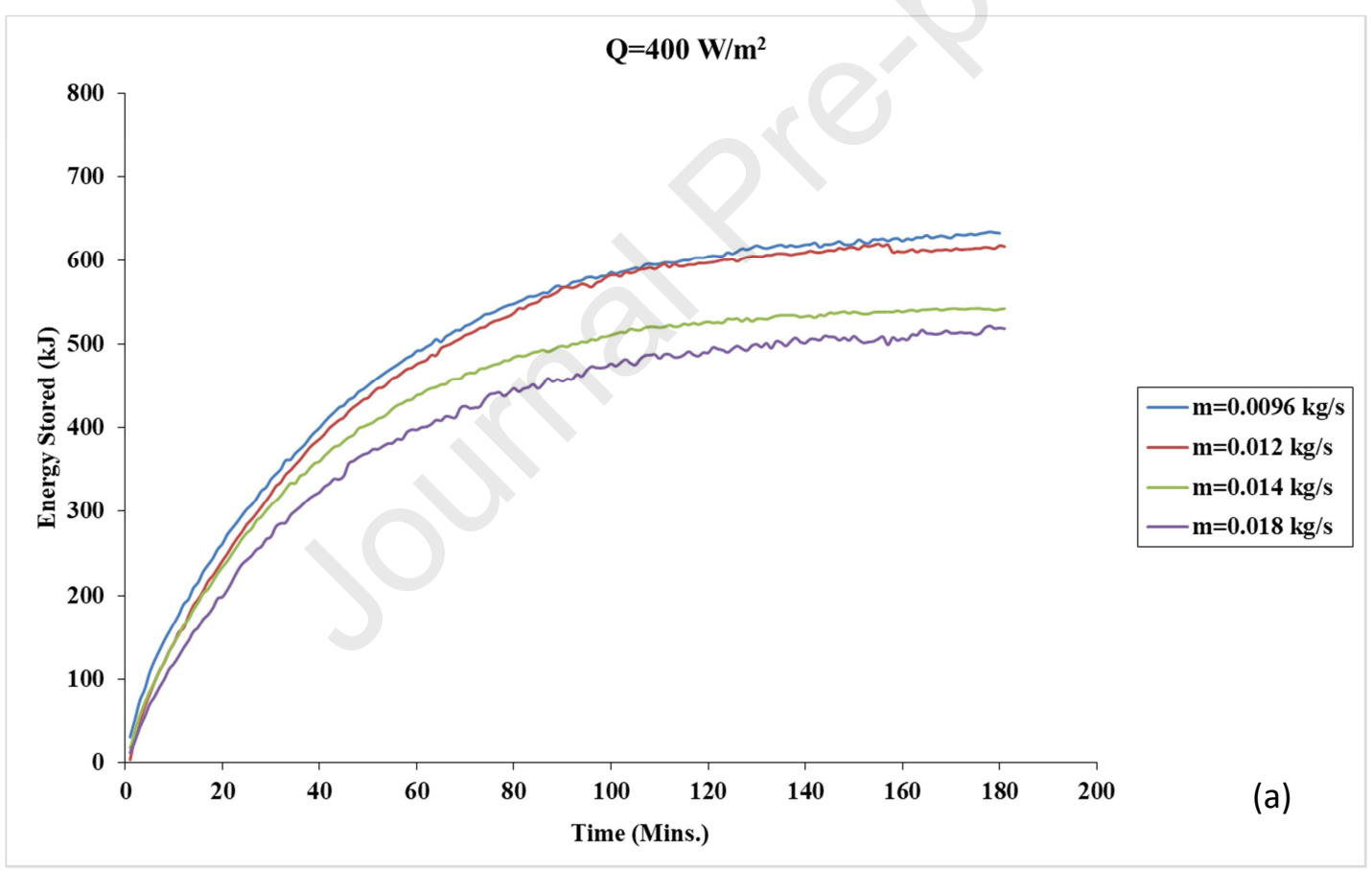




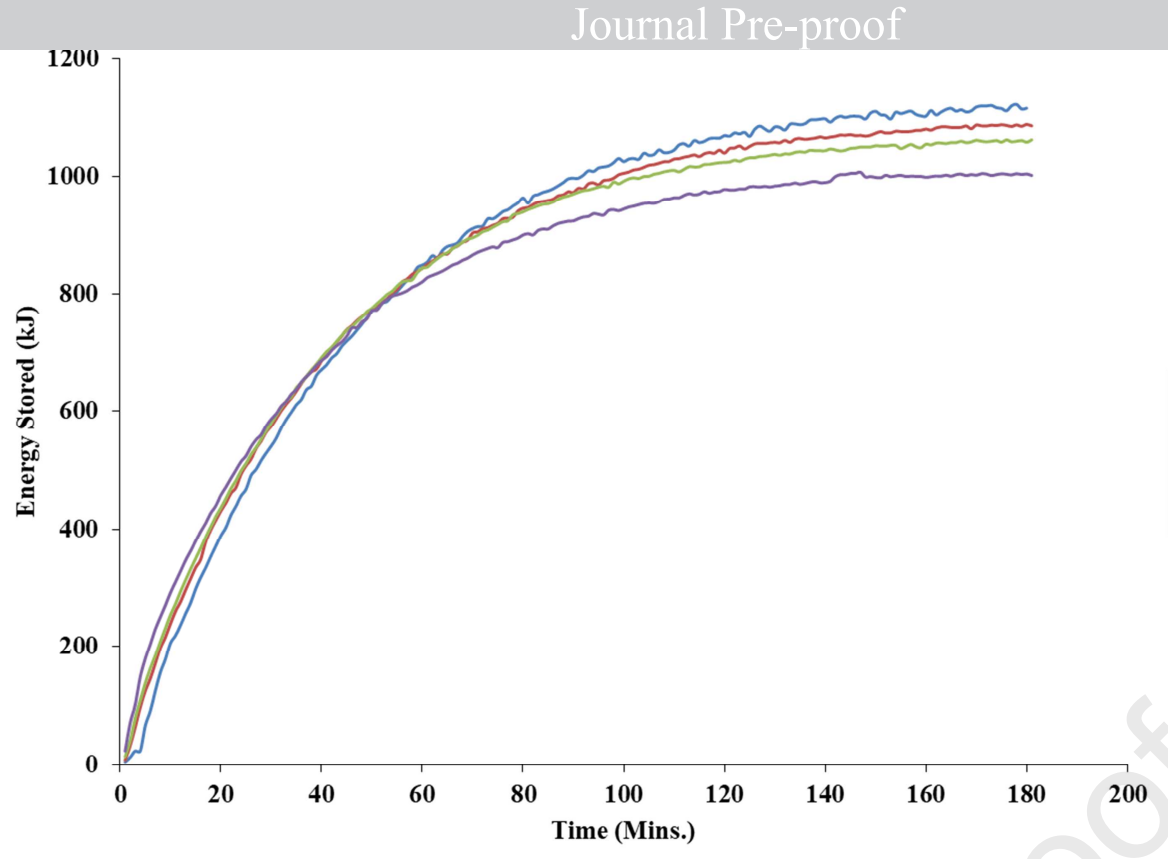

Fig. 4. Variation of average stored energy at different mass flow arte of air. (a) $Q=400 \mathrm{~W} / \mathrm{m}^{2}$; (b) $Q=800 \mathrm{~W} / \mathrm{m}^{2}$.

\subsubsection{Variation of thermal efficiency during charging}

The variation of thermal efficiency of the collectors with time at various air mass flow rates is shown in Fig. 6a-b. In general, the collector efficiency is found to increase with time and the rate of increase is higher at the beginning and thereafter it tends to reduce. With time, the surface temperature of the absorber increases due to absorption of incident solar radiation resulting in an increase in the temperature difference between the inlet air and absorber. But after some time, the heat extraction capacity of the flowing air reaches saturation and thus a reduction in the rate of increase is observed. Moreover, the amount of heat lost also plays a decisive role at higher absorber/system temperatures [2] as the amount of the top (leakage) heat losses is directly proportional to the system temperature. Results indicate that the increase in air mass flow rate helps to enhance the thermal efficiency due to better mixing of air within the collector. The maximum thermal efficiency was found to be $40 \%$ and $42 \%$ for 400 and $800 \mathrm{~W} / \mathrm{m}^{2}$, respectively, at air mass flow rates of $0.018 \mathrm{~kg} / \mathrm{s}$. It can be seen from Fig. $6 \mathrm{a}-\mathrm{b}$, that the increase in air mass flow rate by 
respectively.

It may be said from the energy balance it is clear that the total energy accumulated on the

338 solar collector is being used to enhance the temperature of the absorber and other components of 339 the collector. Further, since the absorber is attached with the sand (acting as a storage), thus, 340 increase in temperature of the absorber is linked with the increase in the temperature of the storage.

341 The travelling air gets heat up by taking heat from the absorber. In the beginning, on one side the 342 inlet insolation is mostly used to increase the temperature of the absorber and thus the storage. On 343 the other side, until the temperature of the absorber is increased to a certain value, due to lower temperature gradient between the inlet air and the absorber, travelling air is unable to extract much heat. These combined factors are the reasons for initial peak in the value of charging efficiency, which is a ratio of heat absorbed by the storage to the total energy accumulated in the collector.

347 However, with passage of time, as the temperature of the absorber cum storage is increased, the 348 amount of energy carried away by the travelling air gets increased. This finally results in increase of the thermal efficiency of the SAC and during this period of time, the charging efficiency remains lower. 

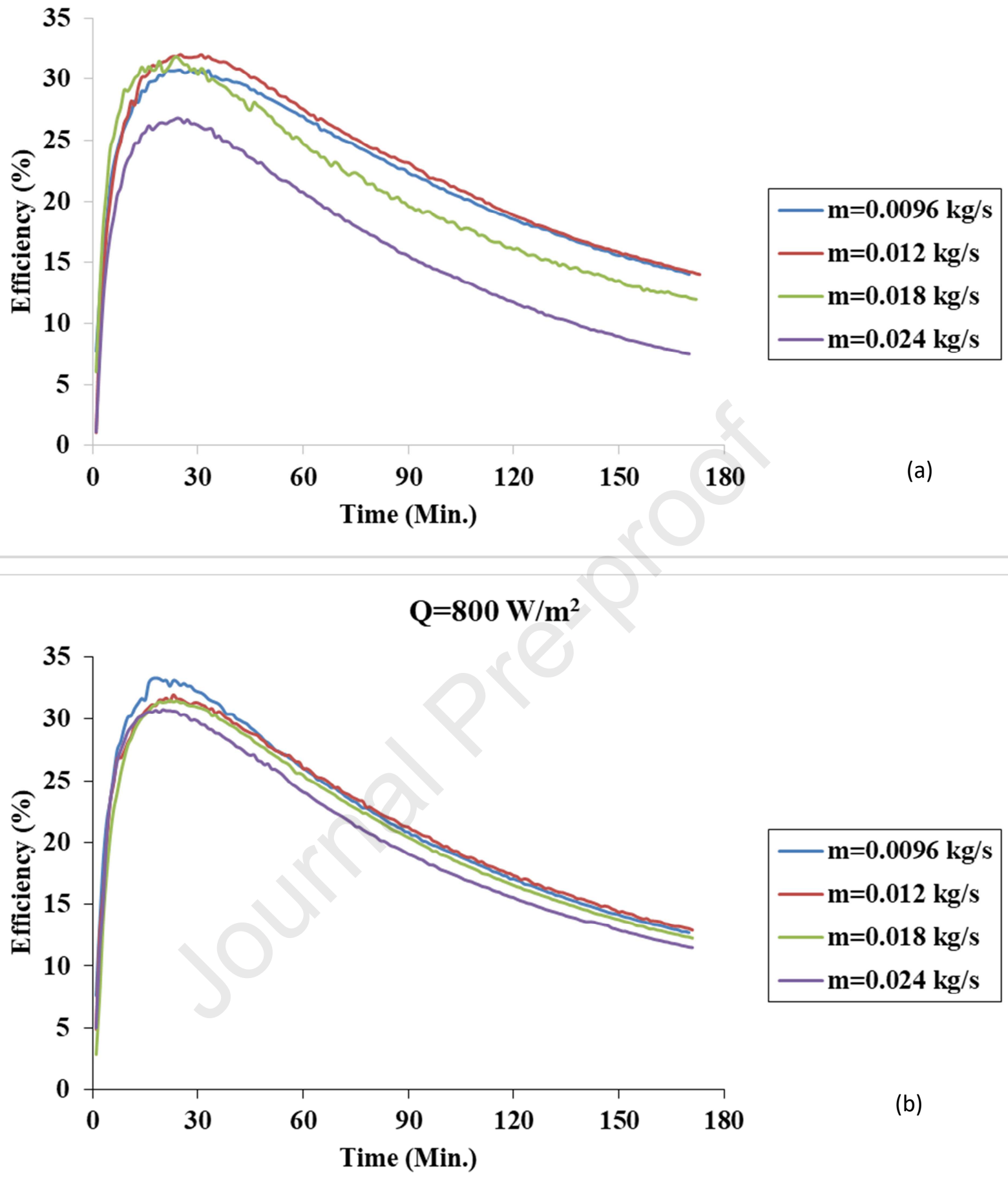

Fig. 5. Variation of charging efficiency. (a) $Q=400 \mathrm{~W} / \mathrm{m}^{2}$; (b) $Q=800 \mathrm{~W} / \mathrm{m}^{2}$. 

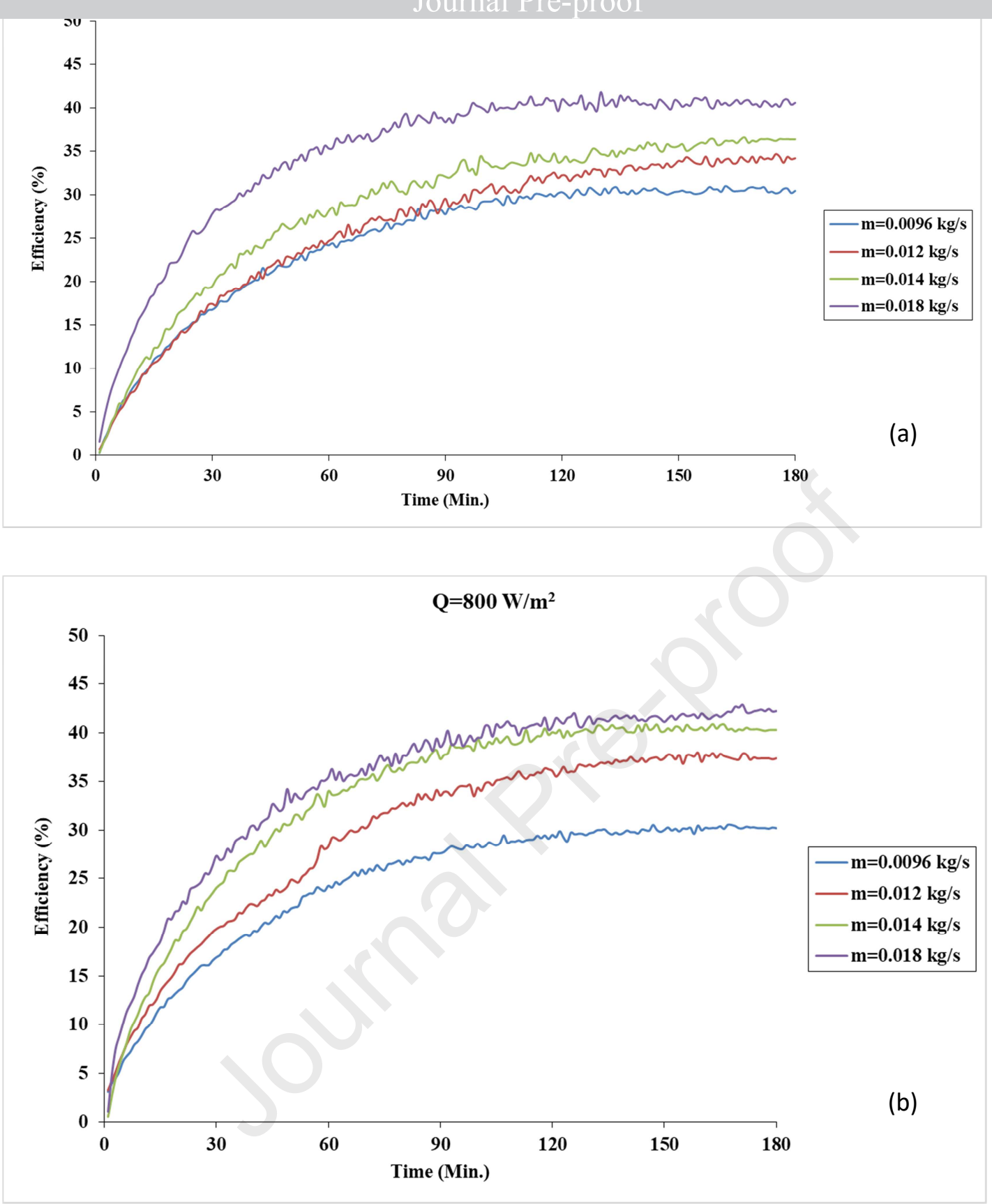

Fig. 6. Variation of thermal efficiency during charging. (a) $Q=400 \mathrm{~W} / \mathrm{m}^{2}$; (b) $Q=800 \mathrm{~W} / \mathrm{m}^{2}$.

\subsection{Discharging Mode}

\subsubsection{Average sand temperature}

The variation of average storage (sand) temperature during the discharging mode at different axial

363 positions is shown in Fig. 7a-d. The positions are identical to that in the charging mode (Fig. 3a-d).

364 As can be seen that the trend of decrease in temperature is similar during discharging to that of the 
366

367

368

369

370

371

372

373

374

375

376
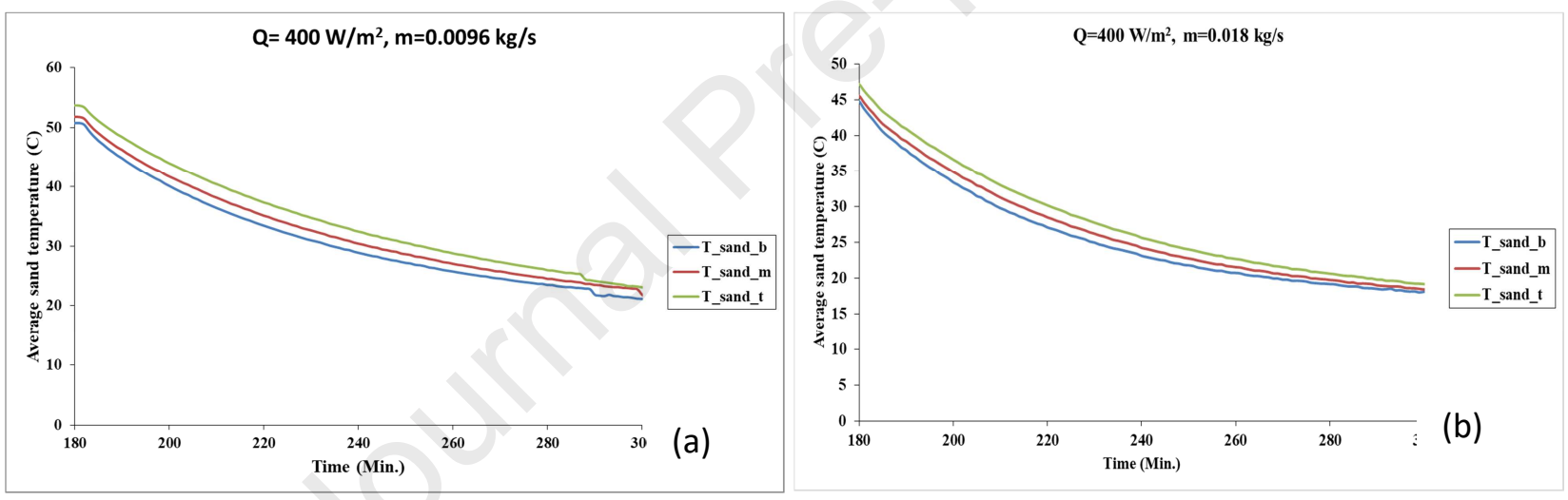

temperature of the flowing air and that results in a reduction of heat absorbing capacity of the fluid in the downstream. An increase in the air mass flow rate results in lower storage temperature during charging but during discharging it extracts heat at a faster rate. The total charging time was around $180 \mathrm{~min}$., whereas, the discharging time was around $120 \mathrm{~min}$. Results indicate that for the collector charged at lower intensity $\left(400 \mathrm{~W} / \mathrm{m}^{2}\right)$ the sand temperature approaches to the surrounding environmental temperature $\left(25^{\circ} \mathrm{C}\right)$ after 50 to $60 \mathrm{~min}$. of discharging. The discharge rate is faster at a higher mass flow rate. At higher intensity, the trend is very similar to that of the lower intensity conditions, except that the sand temperatures attains higher values. Results showed that it took around $120 \mathrm{~min}$. for the sand temperature to drop to ambient levels at a low air mass flow rate and around 100 to $110 \mathrm{~min}$. at higher mass flow rate.

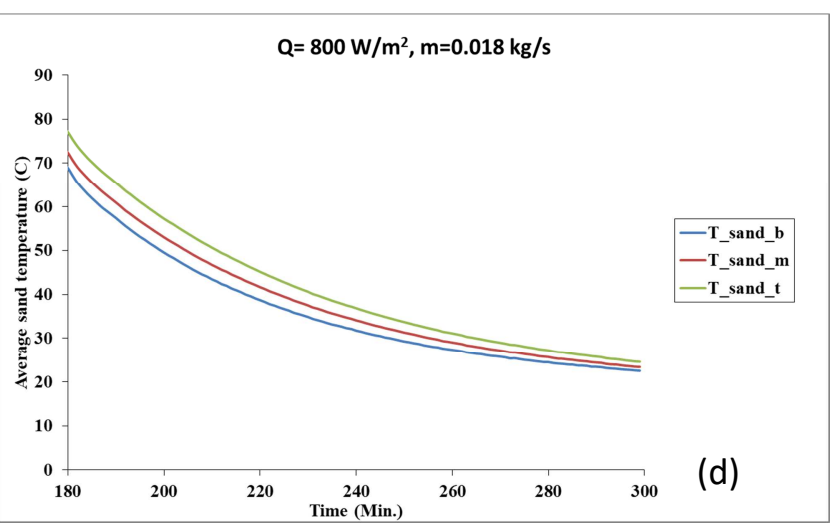

378 Fig. 7. Variation of average storage (sand) temperature during discharging. (a) $Q=400 \mathrm{~W} / \mathrm{m}^{2}$, $m=0.0096 \mathrm{~kg} / \mathrm{s}$; (b) $Q=400 \mathrm{~W} / \mathrm{m}^{2}, m=0.018 \mathrm{~kg} / \mathrm{s}$; (c) $Q=800 \mathrm{~W} / \mathrm{m}^{2}, m=0.0096 \mathrm{~kg} / \mathrm{s}$; (d) $Q=800 \mathrm{~W} / \mathrm{m}^{2}$, $m=0.018 \mathrm{~kg} / \mathrm{s}$. 
382

383

384

385

386

387

388

389

390

391

392

393

394

395

396

397

398

399

400

401

402

403

404

405

\subsubsection{Discharging of the stored energy}

The variation in the percentage of energy discharged for different intensities is depicted in Fig. 8a-

b. The total amount of stored energy during charging at a lower intensity of radiation is always lower than that at a higher intensity due to the amount energy incident on the absorber. Furthermore, at a lower mass flow rate the amount of energy stored is higher, due to lower rate of heat extraction by the flowing air (see Fig. 8a-b). During discharge, the rate of extraction of heat from the stored energy (sand) is always higher at higher mass flow rates. Furthermore, a quantitative comparison of lower and higher intensities indicates that the rate of percentage discharge is comparatively higher for the system when charged at a lower level of radiation. For an example, for a mass flow rate of $0.018 \mathrm{~kg} / \mathrm{s}$, almost $50 \%$ of the stored energy is discharged after 32 min. at lower intensity of radiation, whereas it takes almost 40 min., while charging at a higher intensity. The thermal energy stored in the sand is negligible after $80 \mathrm{~min}$. of discharged period at lower intensity test conditions.

\subsubsection{Average discharging efficiency}

The variation of the average discharging efficiency is shown in Fig. 9. The discharging efficiency is the representation of the conversion of stored energy into useful heat. Results indicate that the increase in the air mass flow rate from $0.0096 \mathrm{~kg} / \mathrm{s}$ to $0.012 \mathrm{~kg} / \mathrm{s}$ resulted in an increase in the discharging efficiency due to better and faster extraction of the heat. This may also be linked with two factors: one is the magnitude of stored energy reduces with the increase mass flow rate of air; and other is the reduction in the temperature of the storage which helps to reduce the top losses. A further increase in the mass flow rate up to $0.018 \mathrm{~kg} / \mathrm{s}$ resulted in monotonic decrease of the discharging efficiency by up to $9 \%$ compared to that at $0.0096 \mathrm{~kg} / \mathrm{s}$. This is due to the faster rate of discharge of stored energy at higher air mass flow rates. 

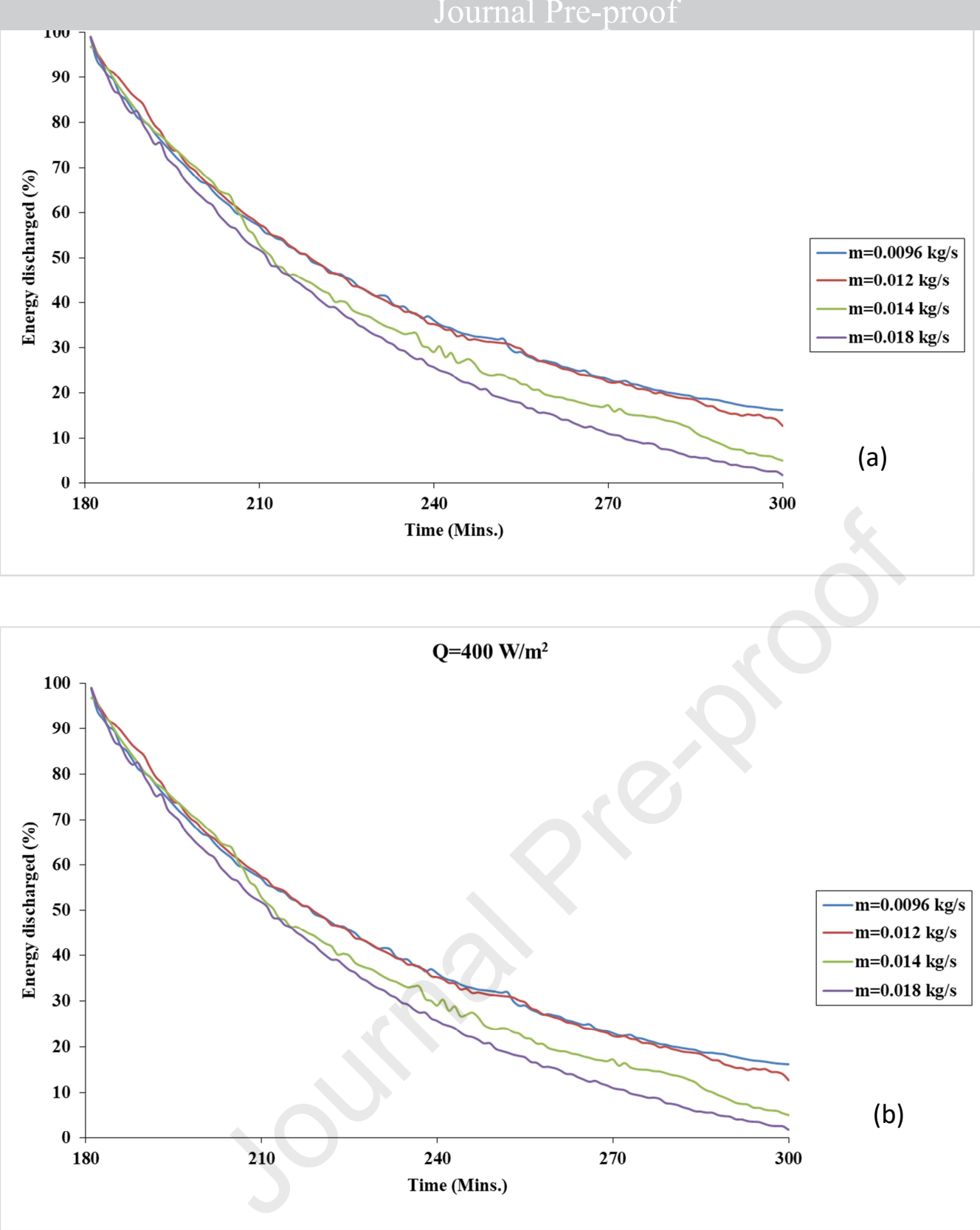

Fig. 8. Percentage variation of energy discharged. (a) $Q=400 \mathrm{~W} / \mathrm{m}^{2}$; (b) $Q=800 \mathrm{~W} / \mathrm{m}^{2}$.

At higher levels of radiation intensity, increasing the mass flow rate from 0.0096 to 0.012 $\mathrm{kg} / \mathrm{s}$ results in increase in the discharging efficiency by almost $15 \%$. It is important to mention that at higher levels of radiation, the amount of losses are also high due to a higher system temperature.

412 Thus, an increase in the mass flow rate of air extracts more heat and reduces the system temperature 413 resulting in decrease in top (leakage) losses. These combined factors might be the reasons for a 414 higher rate of increase in discharging efficiency at higher radiation intensities. However, a further 415 increase in the air mass flow rate up to $0.018 \mathrm{~kg} / \mathrm{s}$ resulted in a continuous decrease in the 
417 discharging efficiency depends on the air mass flow rate, and it reaches a maximum at a certain

418 flow rate. In addition, an increase in the air mass flow rate not only decreases the discharging efficiency but also reduces the desired output temperature of the flowing air.

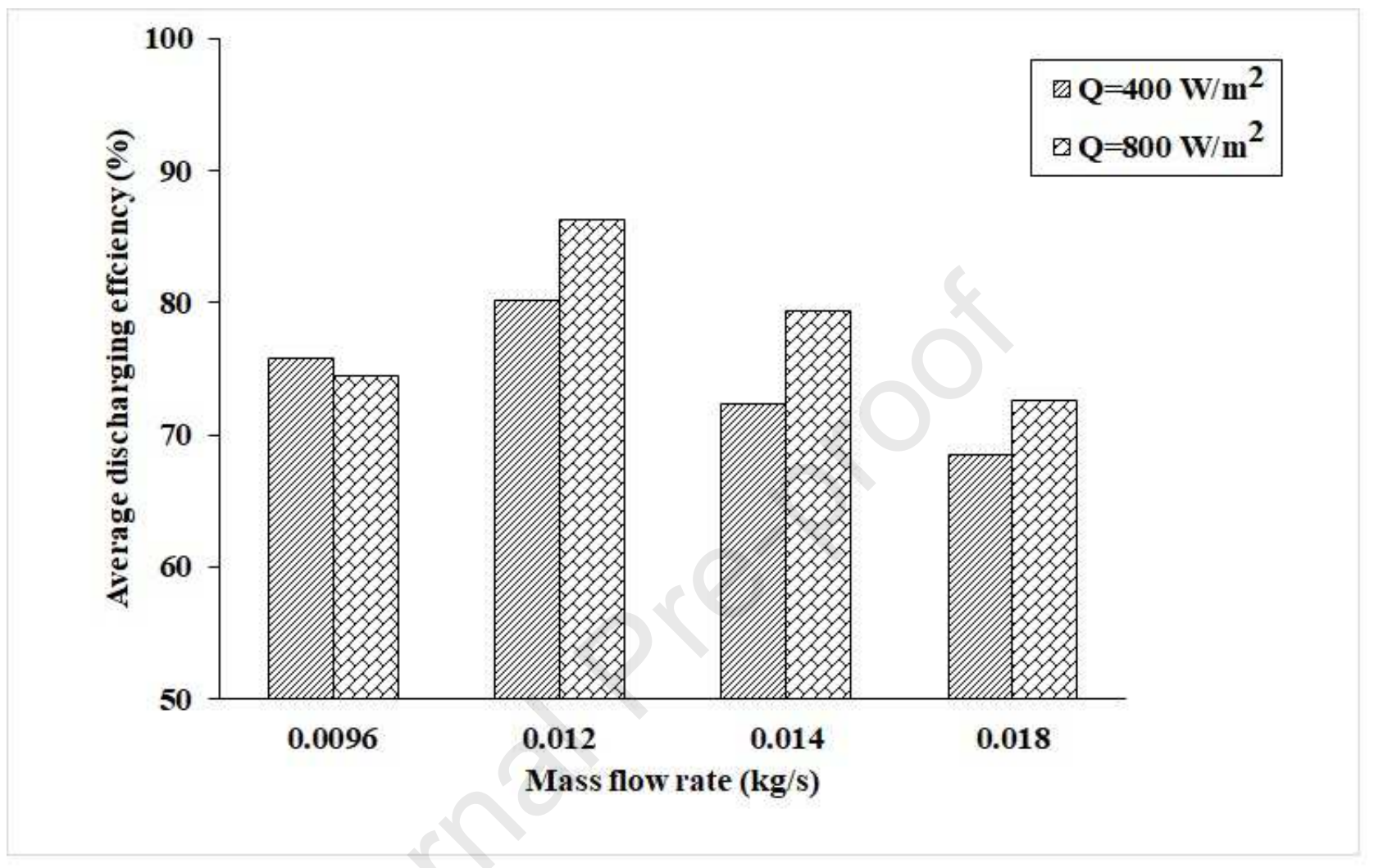

Fig. 9. Variation of average discharging efficiency.

The variation of thermal efficiency $(\eta)$ and the corresponding output temperature $(T)$ with air mass flow rate is presented in Figs. 10a-b. The data having notation 'black' and 'sand_5cm' hass taken

427 from Das et al. [4], representing the collector with an aluminium absorber coated with only black 428 paint and sand coated with an air gap of $5 \mathrm{~cm}$. The air gap for the present study was reduced to 3 $429 \mathrm{~cm}$ due to the use of the polycarbonate sheet (noted as 'poly'). Furthermore, for comparison 
noted as 'sand_3cm'.

At lower solar insolation levels (Fig. 10a), the results reveal that in general the efficiency increases with the increase in the air mass flow rate due to the better heat extraction. This is a result of better mixing of the fluid coupled with an increase in the heat extraction capacity of the flowing air. Furthermore, the presence of the sand coating in the absorber improves the heat transfer and the corresponding collector efficiency by almost $28 \%$ over that of the black coated absorber (with a 3 $\mathrm{cm}$ air gap) at lower air mass flow rates. The increase in efficiency with the sand coating is up to $13 \%$, at higher air mass flow rate. Absorption of solar radiation by the successive layers of sand on the absorber surface acting as a volumetric phenomenon as compared to the surface phenomenon in case of the conventional collector [8]. Furthermore, the presence of the sand coating helps to increase the level of turbulence [4] which results in better mixing of the fluid which in turn increases the thermal efficiency by up to $17 \%$ [4]. The trend in the output temperature is in line with the trend of efficiency. With the increase in the air mass flow rate, the output temperature drops continuously due to the lower retention time of the flowing air. However part of the reduction of the total heat transfer due to reduction of output temperature is partially overcome by the increase in the air mass flow rate.

The reduction in the air gap from $5 \mathrm{~cm}$ to $3 \mathrm{~cm}$ provided an $11 \%$ higher efficiency at lower air mass flow rates (Fig. 10a). With higher air gaps, the total amount of fluid retained in the collector is higher and most of the flowing fluid tends to pass through the less resistive zone in between the absorber and glazing. Furthermore, at lower air mass flow rates, the air temperature is comparatively higher in the convection mode of heat transfer which plays an important role within the air gap. This results in higher convection losses through the glazing due to cross stream flow within the air gap, especially at wider air gaps. At higher air mass flow rates, due to lower temperature of the system, the level of convection losses tends to reduce due to the restricted crossstream flow, which also indicates the dominance of forced convection, especially at higher air gaps. 
457 the collector by around 5\% at higher air gaps and higher air mass flow rates of $0.014 \mathrm{~kg} / \mathrm{s}$.

Regarding the sand coated sand filled (SCSF) polycarbonate sheet based absorber, at lower levels of insolation (Fig. 10a), a continuous improvement in the performance of the collector is observed as compared to the traditional flat plate collector. The reduction of back losses in the presence of storage based absorber, and also the reduction of top losses due to lower surface temperature of the absorber might be the reason for the same. As can be seen, with a mass flow rate of $0.0096 \mathrm{~kg} / \mathrm{s}$ and radiation level of $400 \mathrm{~W} / \mathrm{m}^{2}$, the value of $\Delta T_{\text {absorber }}$ is around $20^{\circ} \mathrm{C}$ with the polycarbonate based absorber (Fig. 2a), whereas, the same temperature position is around $35^{\circ} \mathrm{C}$ for the sand coated aluminium based absorber [4]. Overall the sand coated sand filled polycarbonate sheet based absorber provided up to a $39 \%$ improvement in efficiency at a lower mass flow rate of $0.0096 \mathrm{~kg} / \mathrm{s}$ than that of the black paint coated aluminium absorber and $20 \%$ higher than the sand coated aluminium absorber. For an air velocity of around $0.9 \mathrm{~m} / \mathrm{s}$ with Granular carbon added solar air collector the maximum temperature of $37.4^{\circ} \mathrm{C}$ was observed by Saxena et al. [7].

At a higher intensity $\left(800 \mathrm{~W} / \mathrm{m}^{2}\right)$, the trend of efficiency and output temperatures are almost the same (Fig. 10b), except the magnitude. Results showed that at a lower mass flow rate of 0.0096 $\mathrm{kg} / \mathrm{s}$, the thermal efficiency of the sand coated sand filled (SCSF) polycarbonate sheet based absorber is almost $40.5 \%$ and $25 \%$ higher than that of the black paint coated aluminium absorber and sand coated aluminium absorber, respectively. However, at a higher mass flow rate of 0.018 $\mathrm{kg} / \mathrm{s}$, the sand coated absorber with an air gap of $5 \mathrm{~cm}$ provided the highest efficiency. This is due to the dominance of forced convection coupled with comparatively lower absorber surface temperature since part of the heat is being absorbed by the sand storage. Furthermore, compared to lower levels of radiation, the collector efficiency for $5 \mathrm{~cm}$ air gap is lower than that for the $3 \mathrm{~cm}$ air gap at a mass flow rate of $0.014 \mathrm{~kg} / \mathrm{s}$. This is an indication of dominance of natural convection at higher levels of solar radiation. Lakshmi et al. [18] had reported that for solar air collector having 

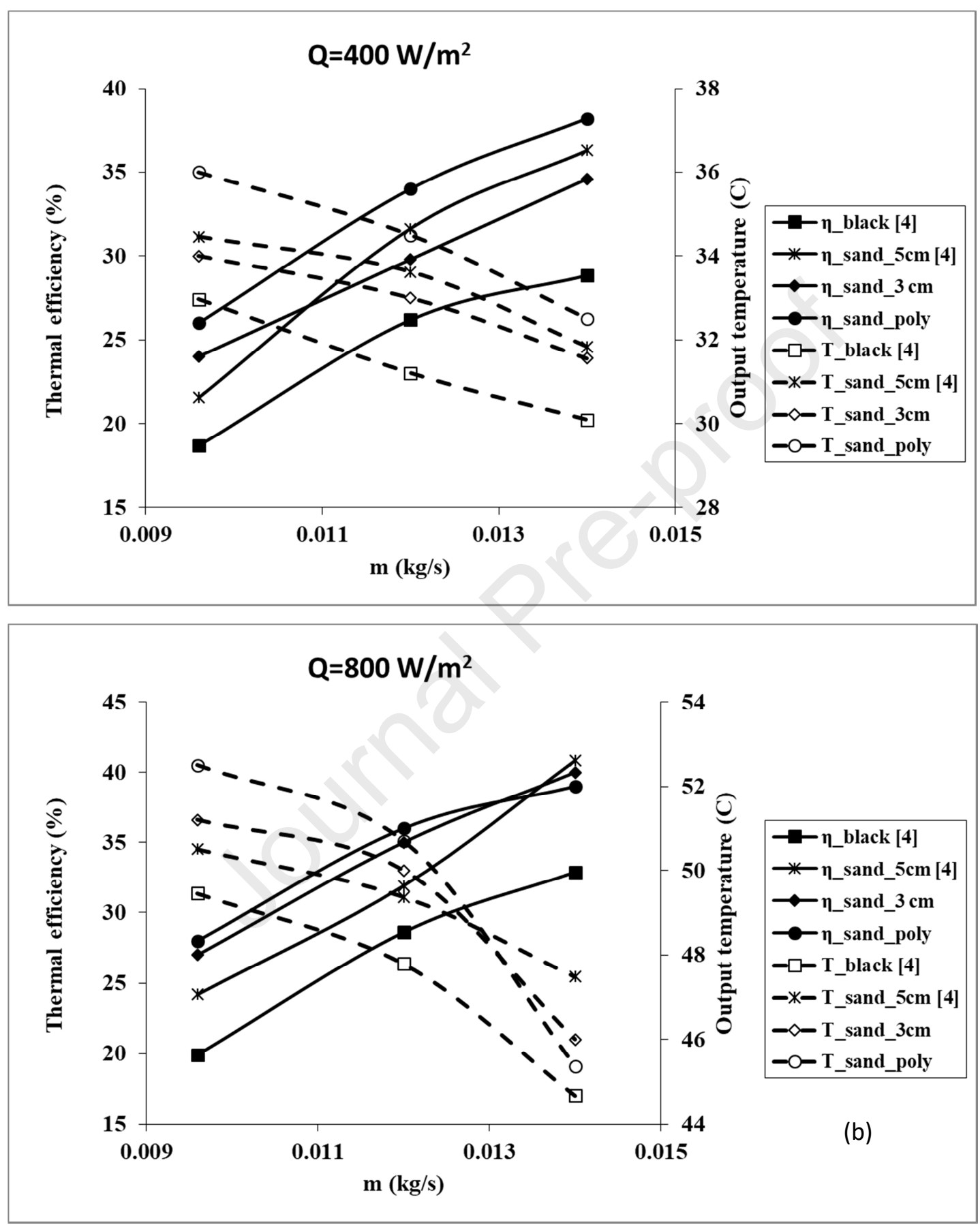

486 Fig. 10. Comparative variation of thermal efficiency and corresponding outlet temperature. (a) $Q=400$

$487 \mathrm{~W} / \mathrm{m}^{2}$; (b) $Q=800 \mathrm{~W} / \mathrm{m}^{2}$ 
The thermal performance characterisation of the sand coated and sand filed (SCSF) polycarbonate

491 sheet based solar air collector (SAC) has been carried out under solar simulated conditions for radiation levels of 400 and $800 \mathrm{~W} / \mathrm{m}^{2}$ and at air flow rates of 0.0096 to $0.0183 \mathrm{~kg} / \mathrm{s}$. The results are compared with a solar air collector with a sand coated aluminium absorber under similar test conditions. A charging and discharging time of 180 and 120 min., respectively were determined. The following observations are made:

- The outlet air temperature was found to increase by almost 18 to $25^{\circ} \mathrm{C}$ at higher levels of radiation.

- The maximum average storage temperature of SAC was $54^{\circ} \mathrm{C}$ and $84{ }^{\circ} \mathrm{C}$, at solar radiation levels of 400 and $800 \mathrm{~W} / \mathrm{m}^{2}$, respectively.

- Increasing the mass flow rate of the air by $87 \%$ resulted in a decrease in the amount of stored energy of SAC by 10 to $24 \%$ due to a higher extraction of heat by the flowing air.

- A maximum thermal efficiency of SAC of around $40 \%$ and $42 \%$ is observed during charging at a mass flow rates of $0.018 \mathrm{~kg} / \mathrm{s}$ at lower and higher levels of solar radiation, respectively. Furthermore, increase in the mass flow rate by $87 \%$ results in enhancement of the thermal efficiency by almost 50 to $53 \%$.

- During discharging, the temperature of the sand comes close to the ambient conditions i.e., at $25^{\circ} \mathrm{C}$, after 50 to $80 \mathrm{~min}$. at lower level of solar radiation $\left(400 \mathrm{~W} / \mathrm{m}^{2}\right)$, whereas, it takes around 100-120 min. at higher levels of radiation $\left(800 \mathrm{~W} / \mathrm{m}^{2}\right)$.

- Increasing the air mass flow rate from 0.0096 to $0.012 \mathrm{~kg} / \mathrm{s}$ resulted an increase in the discharging efficiency by almost $15 \%$ whereas a reduction up to $9 \%$ was observed when the air mass flow rate was $0.0018 \mathrm{~kg} / \mathrm{s}$. This is linked with the higher rate of extraction of heat by the flowing air coupled with lower amount of stored heat.

- A reduction in the air gap from $5 \mathrm{~cm}$ to $3 \mathrm{~cm}$ provided an $11 \%$ higher efficiency at lower air mass flow rates for the SAC with the sand coated aluminium based absorber. 
of the SAC with plain aluminium absorber and $20 \%$ higher than sand coated aluminium absorber based SAC.

518

This study establishes the improvement of the thermal performance of the polycarbonate sheet based solar air collector by using thin layer of sand coating on the absorber and with sand filled to act as a storage-cum-collector.

\section{ACKNOWLEDGEMENT:}

The authors (specifically Biplab Das) sincerely acknowledges the support received from the DBT, Govt. of India, under NE-Overseas Associateship and also thank Ulster University for hosting and allowing to use the laboratory facilities

\section{References}

[1] E. Vengadesan, R. Senthil, A review on recent developments in thermal performance enhancement methods of flat plate solar air collector, Renew. Sustain. Energy Rev., vol. 134 2020.

[2] W. Pang, Y. Cui, Q. Zhang, G.J. Wilson, H. Yan, A comparative analysis on performances of flat plate photovoltaic/thermal collectors in view of operating media, structural designs, and climate conditions, Renew. Sustain. Energy Rev., vol. 119, 2020.

[3] D. R. Tobergte and S. Curtis, "Solar heat worldwide," J. Chem. Inf. Model., vol. 53, no. 9, pp. 1689-1699, 2013.

[4] B. Das, J. D. Mondol, S. Debnath, A. Pugsley, M. Smyth, and A. Zacharopoulos, "Effect of the absorber surface roughness on the performance of a solar air collector: An experimental investigation," Renew. Energy, vol. 152, pp. 567-578, 2020.

[5] R. Karwa and V. Srivastava, "Thermal Performance of Solar Air Heater Having Absorber Plate with V-Down Discrete Rib Roughness for Space-Heating Applications," J. Renew. Energy, vol. 2013, pp. 1-13, 2013.

[6] S. Debnath, B. Das, P. R. Randive, and K. M. Pandey, "Performance analysis of solar air collector in the climatic condition of North Eastern India,” Energy, vol. 165, pp. 281-298, 2018. 
finned air collectors," Energy, vol. 31, no. 4, pp. 452-470, 2006.

545

546

547

548

549

550

551

552

553

554

555

556

557

558

559

560

561

562

563

564

565

566

567

568

569

570

571

572

573

[8] M. Lati, S. Boughali, D. Bechki, H. Bouguettaia, D. Mennouche, N. Gana, S. Ghettas, Experimental investigation on effect of an absorber plate covered by a layer of sand on the efficiency of passive solar air collector, Int. J. Green Energy., vol. 16, pp. 413-422, 2019.

[9] S. Singh, S. K. Chaurasiya, B. S. Negi, S. Chander, M. Nemś, and S. Negi, "Utilizing circular jet impingement to enhance thermal performance of solar air heater," Renew. Energy, vol. 154, pp. 1327-1345, 2020.

[10] R. Vaziri, M. Ilkan, and F. Egelioglu, "Experimental performance of perforated glazed solar air heaters and unglazed transpired solar air heater," Sol. Energy, vol. 119, pp. 251-260, 2015.

[11] P. Velmurugan and R. Kalaivanan, "Energy and exergy analysis of solar air heaters with varied geometries,” Arab. J. Sci. Eng., vol. 40, no. 4, pp. 1173-1186, 2015.

[12] E. Ogbonnaya, L. Weiss, Small-scale flat plate collectors for solar thermal scavenging in low conductivity environments, Int. J. Photoenergy, 2017.

[13] D. Mercs, A. Didelot, F. Capon, J.F. Pierson, B. Hafner, A. Pazidis, S. Föste, R. ReinekeKoch, Innovative Smart Selective Coating to Avoid Overheating in Highly Efficient Thermal Solar Collectors, Energy Procedia., vol. 91, pp. 84-93, 2016.

[14] T. Kiatsiriroat, J. Tiansuwan, T. Suparos, and K. Na Thalang, "Performance analysis of a direct-contact thermal energy storage-solidification," Renew. Energy, vol. 20, no. 2, pp. 195206, 2000.

[15] S. Roy, B. Das, A. Biswas, B.K. Debnath, Energy and Exergy Analysis of a Concrete-Based Thermal Energy Storage System, J. Inst. Eng. Ser. C., vol. 101, pp.517-529, 2020.

[16] G. Kalaiarasi, R. Velraj, M. N. Vanjeswaran, and N. Ganesh Pandian, "Experimental analysis and comparison of flat plate solar air heater with and without integrated sensible heat storage," Renew. Energy, vol. 150, pp. 255-265, 2020.

[17] A. Saxena, N. Agarwal, and G. Srivastava, "Design and performance of a solar air heater with long term heat storage," Int. J. Heat Mass Transf., vol. 60, no. 1, pp. 8-16, 2013.

[18] D. V. N. Lakshmi, A. Layek, and P. M. Kumar, "Performance Analysis of Trapezoidal Corrugated Solar Air Heater with Sensible Heat Storage Material," Energy Procedia, vol. 109, no. November 2016, pp. 463-470, 2017. 
convection flat plate solar air heater with storage material," Therm. Sci., vol. 16, no. 4, pp. 1105-1116, 2012.

577

[20] M. Mohanraj and P. Chandrasekar, "Performance of a forced convection solar drier integrated with gravel as heat storage material," Proc. IASTED Int. Conf. Sol. Energy, SOE 2009, no. May 2014, pp. 51-54, 2009.

580

581

582

583

584

585

586

587

588

589

590

591

592

593

594

595

596

597

598

599

600

601

602

603

604

[21] M. R. I. Ramadan, A. A. El-Sebaii, S. Aboul-Enein, and E. El-Bialy, "Thermal performance of a packed bed double-pass solar air heater," Energy, vol. 32, no. 8, pp. 1524-1535, 2007.

[22] G. Murali, K. Rama Krishna Reddy, M. Trinath Sai Kumar, J. SaiManikanta, and V. Nitish Kumar Reddy, "Performance of solar aluminium can air heater using sensible heat storage," Mater. Today Proc., vol. 21, no. xxxx, pp. 169-174, 2020.

[23] M. Abuşka, S. Şevik, and A. Kayapunar, "Experimental performance analysis of sensible heat storage in solar air collector with cherry pits/powder under the natural convection," Sol. Energy, vol. 200, 2020.

[24] A. Saxena, G. Srivastava, and V. Tirth, "Design and thermal performance evaluation of a novel solar air heater," Renew. Energy, vol. 77, pp. 501-511, 2015.

[25] Y. Dhote and S. Thombre, "Performance Analysis and Parametric Study of a Natural Convection Solar Air Heater With In-built Oil Storage," J. Inst. Eng. Ser. C, vol. 97, no. 4, pp. 527-537, 2016.

[26] W. B. Chaouch, A. Khellaf, A. Mediani, M. E. A. Slimani, A. Loumani, and A. Hamid, "Experimental investigation of an active direct and indirect solar dryer with sensible heat storage for camel meat drying in Saharan environment," Sol. Energy, vol. 174, pp. 328-341, 2018.

[27] S. B. Prasad, J. S. Saini, and K. M. Singh, "Investigation of heat transfer and friction characteristics of packed bed solar air heater using wire mesh as packing material," Sol. Energy, vol. 83, no. 5, pp. 773-783, 2009.

[28] S. Aboul-Enein, A. A. El-Sebaii, M. R. I. Ramadan, and H. G. El-Gohary, "Parametric study of a solar air heater with and without thermal storage for solar drying applications," Renew. Energy, vol. 21, no. 3-4, pp. 505-522, 2000.

[29] P. Naphon, "Effect of porous media on the performance of the double-pass flat plate solar air heater," Int. Commun. Heat Mass Transf., vol. 32, no. 1-2, pp. 140-150, 2005. 

packed bed solar air heater for a low porosity system," Sol. Energy, vol. 74, no. 4, pp. 319$329,2003$.

[31] P. T. Saravanakumar and K. Mayilsamy, "Forced convection flat plate solar air heaters with 609 and without thermal storage," J. Sci. Ind. Res. (India). vol. 69, no. 12, pp. 966-968, 2010.

[32] S. Vijayan, T. V. Arjunan, A. Kumar, Exergo-environmental analysis of an indirect forced convection solar dryer for drying bitter gourd slices, Renew. Energy. Vol. 146 pp. 2210$2223,2020$.

\section{Nomenclature:}

$614 A_{c}$

Collector area $\left(\mathrm{m}^{2}\right)$

$615 A_{s c}$

Area of the absorber $\left(\mathrm{m}^{2}\right)$

$616 C_{p, s}$

Specific heat of sand $\left(\mathrm{W} / \mathrm{m}^{2} \mathrm{~K}\right)$

$617 C_{p, a}$

Specific heat of air $\left(\mathrm{W} / \mathrm{m}^{2} \mathrm{~K}\right)$

$618 I$

Solar irradiation $\left(\mathrm{W} / \mathrm{m}^{2}\right)$

$619 m_{a}$

Air mass flow rate $(\mathrm{kg} / \mathrm{s})$

$620 m_{p}$

Mass of the sensible storage material (i.e., sand) (kg)

$621 Q_{a b}$

Absorbed energy by the absorber/storage (W)

$622 Q_{a c}$

Accumulated energy (W)

$623 Q_{\text {loss }}$

Lost energy (W)

$624 Q_{u}$

Useful heat energy gain (W)

$625 T_{a, \text { out }}$

Outlet air temperature $\left({ }^{\circ} \mathrm{C}\right)$

$626 T_{a, \text { in }}$

Inlet air temperature $\left({ }^{\circ} \mathrm{C}\right)$

$627 T_{p, \text { average }}$

Average temperature of sand air $\left({ }^{\circ} \mathrm{C}\right)$

$628 T_{e}$

Temperature of the environment $\left({ }^{\circ} \mathrm{C}\right)$

$629 U_{c}$

Overall heat loss coefficient $\left(\mathrm{W} / \mathrm{m}^{2} \mathrm{C}\right)$ 
$631 \eta_{s, c}$

Charging efficiency or storing efficiency (-)

$632 \eta_{t, c}$

Thermal efficiency of the collectors (-)

$633 \eta_{t, d}$

Thermal efficiency of the collectors during discharging (-)

634

$\rho$

Density of the air $\left(\mathrm{kg} / \mathrm{m}^{3}\right)$ 
Table 1 Summary of performance of various solar air heaters using sensible heat storage materials.

\begin{tabular}{|c|c|c|c|c|c|c|c|}
\hline Reference & $\begin{array}{l}\text { Absorber and flow } \\
\text { type }\end{array}$ & Storage material & Cover & $\begin{array}{l}\text { Dimensions of } \\
\text { the collector }\end{array}$ & $\begin{array}{l}\text { Convection } \\
\text { type }\end{array}$ & $\begin{array}{l}\text { Air gap } \\
(\mathbf{m m})\end{array}$ & Results \\
\hline $\begin{array}{l}\text { Kalaiarasi et al. } \\
{[16]}\end{array}$ & $\begin{array}{l}\text { Flat aluminium plate } \\
\text { black coated; black } \\
\text { painted copper fins, } \\
\text { single flow }\end{array}$ & Therminol & $\begin{array}{l}\text { Single, } \\
\text { glass }\end{array}$ & $2 \mathrm{~m} \times 2 \mathrm{~m}$ & Forced & 30 & $\eta_{\text {therm }}$ was notified $70.8 \%$ maximum \\
\hline $\begin{array}{l}\text { Saxena et al. } \\
\text { [17] }\end{array}$ & $\begin{array}{l}\text { Flat plate black coated, } \\
\text { single flow }\end{array}$ & Granular carbon & $\begin{array}{l}\text { Single, } \\
\text { glass }\end{array}$ & $1.51 \mathrm{~m} \times 7 \mathrm{~m}$ & $\begin{array}{l}\text { Natural and } \\
\text { forced }\end{array}$ & 100 & $\begin{array}{l}\eta_{\text {therm }} \text { was notified } 20.7 \%, 73.6 \% \\
\text { maximum for natural and forced } \\
\text { convection, respectively }\end{array}$ \\
\hline $\begin{array}{l}\text { Laxmi et al. } \\
{[18]}\end{array}$ & $\begin{array}{l}\text { Flat plate; trapezoidal } \\
\text { groove black coated, } \\
\text { single flow }\end{array}$ & Gravels & $\begin{array}{l}\text { Single, } \\
\text { glass }\end{array}$ & $2 \mathrm{~m} \times 1 \mathrm{~m}$ & Natural & - & $\begin{array}{l}\eta_{\text {therm }} \text { was notified } 58.16 \% \text { maximum } \\
\text { for trapezoidal corrugated absorber }\end{array}$ \\
\hline Aissa et al. [19] & $\begin{array}{l}\text { Flat plate black coated, } \\
\text { single flow }\end{array}$ & Granite stones & $\begin{array}{l}\text { Single, } \\
\text { glass }\end{array}$ & $2.1 \mathrm{~m} \times 0.84 \mathrm{~m}$ & Forced & 150 & $\begin{array}{l}\text { Outlet air temperature was observed } \\
10-25^{\circ} \mathrm{C} \text { more than ambient air temp. }\end{array}$ \\
\hline $\begin{array}{l}\text { Mohanraj and } \\
\text { Chanderasekar } \\
{[20]}\end{array}$ & $\begin{array}{l}\text { Copper flat plate black } \\
\text { coated, } \\
\text { single flow }\end{array}$ & $\begin{array}{l}\text { Sand mixed with } \\
\text { aluminium scraps }\end{array}$ & $\begin{array}{l}\text { Single, } \\
\text { glass }\end{array}$ & $2 \mathrm{~m} \times 1 \mathrm{~m}$ & Forced & 25 & $\eta_{\text {therm }}$ was estimated about $21 \%$ \\
\hline $\begin{array}{l}\text { Ramdan et al. } \\
\text { [21] }\end{array}$ & $\begin{array}{l}\text { Flat plate, } \\
\text { double flow }\end{array}$ & Limestone and gravel & $\begin{array}{l}\text { Double, } \\
\text { glass }\end{array}$ & - & Forced & 120 & $\begin{array}{l}\eta_{\text {therm }} \text { with gravel or limestone as SHM } \\
\text { was improved by } 28.3 \% \text { and } 25.6 \% \text {, } \\
\text { respectively than system without SHM }\end{array}$ \\
\hline $\begin{array}{l}\text { Murali et al. } \\
\text { [22] }\end{array}$ & $\begin{array}{l}\text { Aluminium can, } \\
\text { single flow }\end{array}$ & $\begin{array}{l}\text { Aluminium } \\
\text { scrapes and pebble stones }\end{array}$ & $\begin{array}{l}\text { Single, } \\
\text { glass }\end{array}$ & $\begin{array}{l}1.36 \mathrm{~m} \times 0.76 \\
\mathrm{~m} \times 0.0125 \mathrm{~m}\end{array}$ & Forced & - & $\begin{array}{l}\eta_{\text {therm }} \text { was notified } 69.8 \% \text { maximum for } \\
\text { aluminium scrapes as SHM }\end{array}$ \\
\hline $\begin{array}{l}\text { Abuska et al. } \\
{[23]}\end{array}$ & $\begin{array}{l}\text { Flat plate black coated, } \\
\text { single flow }\end{array}$ & Cherry pits/powder & $\begin{array}{l}\text { Single, } \\
\text { glass }\end{array}$ & $\begin{array}{l}1 \mathrm{~m} \times 2 \mathrm{~m} \times \\
0.2 \mathrm{~m}\end{array}$ & Natural & 120 & $\eta_{\text {therm }}$ was notified $27.1 \%$ maximum \\
\hline $\begin{array}{l}\text { Saxena et al. } \\
\text { [24] }\end{array}$ & Flat plate black coated & $\begin{array}{l}\text { Dessert sand and granular } \\
\text { carbon }\end{array}$ & $\begin{array}{l}\text { Single, } \\
\text { glass }\end{array}$ & $\begin{array}{l}1.51 \mathrm{~m} \times 0.70 \\
\mathrm{~m}\end{array}$ & $\begin{array}{l}\text { Natural and } \\
\text { forced }\end{array}$ & 100 & $\begin{array}{l}\eta_{\text {therm }} \text { was notified } 20.7 \% \text { and } 80.1 \% \\
\text { maximum for natural and forced } \\
\text { convection, respectively }\end{array}$ \\
\hline $\begin{array}{l}\text { Dhote and } \\
\text { Thombre [25] }\end{array}$ & Flat copper plate & Unused engine oil & $\begin{array}{l}\text { Single, } \\
\text { glass }\end{array}$ & $2 \mathrm{~m} \times 1 \mathrm{~m}$ & Natural & 40 & $\begin{array}{l}\text { Highest overall efficiency of } 16.8 \% \\
\text { was reported }\end{array}$ \\
\hline
\end{tabular}




\begin{tabular}{|c|c|c|c|c|c|c|c|}
\hline $\begin{array}{l}\text { Chaouch et al. } \\
{[26]}\end{array}$ & Flat plate black coated & Pebbles & Glass & - & Forced & - & $\begin{array}{l}\eta_{\text {therm }} \text { of solar collector was improved } \\
28 \% \text { than system without SHM }\end{array}$ \\
\hline $\begin{array}{l}\text { Prasad et al. } \\
\text { [27] }\end{array}$ & $\begin{array}{l}\text { Flat plate with two } \\
\text { different ducts }\end{array}$ & Wire mesh & $\begin{array}{l}\text { Double, } \\
\text { glass }\end{array}$ & $1.65 \mathrm{~m} \times 0.4 \mathrm{~m}$ & - & 25 & $\begin{array}{l}53.3 \% \text { to } 68.5 \% \text { improvement was } \\
\text { noticed in } \eta_{\text {therm }}\end{array}$ \\
\hline $\begin{array}{l}\text { Aboul-Enein et } \\
\text { al. [28] }\end{array}$ & Flat plate black coated & Sand, granite and water & $\begin{array}{l}\text { Single, } \\
\text { glass }\end{array}$ & - & Natural & - & $\begin{array}{l}\text { Outlet air temperature was observed } \\
\text { highest for sand }\end{array}$ \\
\hline Naphon [29] & $\begin{array}{l}\text { Flat plate, } \\
\text { double flow }\end{array}$ & Porous media & $\begin{array}{l}\text { Single, } \\
\text { glass }\end{array}$ & - & 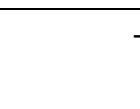 & - & $\begin{array}{l}\eta_{\text {therm }} \text { was improved } 25.9 \% \text { than SAH } \\
\text { without porous media }\end{array}$ \\
\hline $\begin{array}{l}\text { Thakur et al. } \\
{[30]}\end{array}$ & $\begin{array}{l}\text { Flat plate black coated } \\
\text { with two different ducts }\end{array}$ & Wire screen matrix & $\begin{array}{l}\text { Double, } \\
\text { glass }\end{array}$ & $2.4 \mathrm{~m} \times 0.4 \mathrm{~m}$ & Forced & 25 & $\begin{array}{l}\text { Improved heat transfer rate was } \\
\text { noticed }\end{array}$ \\
\hline $\begin{array}{l}\text { Saravanakumar } \\
\text { and Mayilsamy } \\
{[31]}\end{array}$ & $\begin{array}{l}\text { Flat plate black coated, } \\
\text { double flow }\end{array}$ & $\begin{array}{l}\text { Sand, sand with iron } \\
\text { scraps, gravel and gravel } \\
\text { with iron scraps }\end{array}$ & $\begin{array}{l}\text { Single, } \\
\text { glass }\end{array}$ & $0.3 \mathrm{~m} \times 0.3 \mathrm{~m}$ & Forced & 25 & $\begin{array}{l}\eta_{\text {therm }} \text { and outlet air temperature was } \\
\text { improved by10-20\% than SAH without } \\
\text { storage media }\end{array}$ \\
\hline $\begin{array}{l}\text { Vijayan et al. } \\
\text { [32] }\end{array}$ & $\begin{array}{l}\text { corrugated plate black } \\
\text { coated }\end{array}$ & Pebbles & $\begin{array}{l}\text { Single, } \\
\text { glass }\end{array}$ & $2 \mathrm{~m} \times 1 \mathrm{~m}$ & Forced & 30 & $\begin{array}{l}\text { Maximum exergy efficiency of } 54.3 \% \\
\text { was achieved }\end{array}$ \\
\hline
\end{tabular}

$* \eta_{\text {therm }}-$ thermal efficiency (\%) 


\section{Highlights}

- Sand filled sand coated (SCSF) polycarbonate based solar collector is presented

- Efficiency of sand storage based collector and aluminium collector is compared

○ $87 \%$ increase in mass flow rate of air lead to $10-24 \%$ decrease in stored energy

- Reduction of air gap to $3 \mathrm{~cm}$ leads to $11 \%$ higher efficiency of aluminium plate based collector

- SCSF polycarbonate sheet based absorber provides $39 \%$ higher thermal efficiency 


\section{Declaration of interests}

$\square$ The authors declare that they have no known competing financial interests or personal relationships that could have appeared to influence the work reported in this paper.

$\square$ The authors declare the following financial interests/personal relationships which may be considered as potential competing interests:

There is no conflicts of interest

Dr. Biplab Das

Post. Doc.

Belfast School of Architecture and the Built Environment

Centre for Sustainable Technologies, 26B03

Ulster University, Northern Ireland, UK

BT37 0QB 
Experimental Performance Analysis of a Novel Sand Coated and Sand Filled

\section{Polycarbonate Sheet Based Solar Air Collector}

\section{Credit author statement}

Biplab Das: Done the experiment and make the draft manuscript

Jayanta Deb Mondol: Revision of the draft manuscript and analysis of the results

Sushant Negi: Preparation of the draft manuscript

Mervyn Smyth: Analysis of the results and revision of the manuscript

Adrian Pugsley: Analysis of the results and revision of the manuscript 